Bulletin of The John Rylands University Library. 88.2 (2006): 133-77.

(This .pdf version reproduces pagination of printed form)

\title{
Collection of Books owned by the Charles Wesley Family in The John Rylands University Library
}

\author{
Randy L. Maddox
}

One of the significant collections in the Methodist Archives at The John Rylands University Library, The University of Manchester (hereafter MARC), is a group of books identified with the Charles Wesley family. This collection includes over 400 volumes, containing nearly 300 distinct titles, of which fewer than half were publications by John and Charles Wesley themselves. As such, it provides important evidence of which other authors were influential on Charles Wesley and his family.

The personal library of John Wesley was split up during his lifetime between the Kingswood school in Bristol and his house in London, and suffered notable depletion over the years at the hands of memorabilia collectors. ${ }^{1}$ By contrast, the core of Charles Wesley's personal library has remained largely intact. This can be demonstrated from a notebook (also present in MARC) that contains Charles Wesley's manuscript catalogue of his personal library in lists dated 1757-64. ${ }^{2}$ About two-thirds of the books in these lists remain in the present Rylands collection. The most frequent items not remaining are music books, dictionaries, and road maps. There are, however, some theological, historical, and literary works on these lists that are not present in this collection - a topic to which I will return.

The integrity of the Rylands collection can be explained by its pedigree. It was purchased in 1831 from Charles Wesley junior, along with a large collection of family manuscripts, by the Wesleyan Methodist Conference through the efforts of Thomas Jackson. ${ }^{3}$

${ }^{1}$ For more on John Wesley’s library, see Randy L. Maddox, 'John Wesley’s Reading: Evidence in the Kingswood School Archives', Methodist History 41.2 (2003): 49-67; and Maddox, 'John Wesley's Reading: Evidence in the Book Collection at Wesley's House, London', Methodist History 41.3 (2003): 118-33.

${ }^{2}$ The notebook is catalogued as MARC, DDCW 8/7. The lists appear on pp 33-53 counting from the front.

${ }^{3}$ The deed of conveyance, dated 4 August 1831, is part of the collection in the Methodist Archives (MARC, MAW Ra (Box 6)). 
Charles junior was anxious to sell the collection because his sister Sarah Wesley, who had long helped manage his resources, had recently died, leaving him both anxious about the future of the materials and in need of money. Jackson held the materials - in trust for the Conference - and added to them a few volumes from other family members. ${ }^{4}$ Then, in 1859 , his entire personal library of some 7,500 volumes was purchased by James Heald, a wealthy Methodist businessman, and donated as the core for library collections at the recently founded Richmond and Didsbury colleges. ${ }^{5}$ The materials related to Charles Wesley were all located at Richmond, where Jackson was tutor.

While the details are less clear, Jackson also arranged for that part of John Wesley's personal library held at the house at City Road Chapel in London to be part of the collection gathered at Richmond. At some point thereafter the two collections of books owned by the Wesleys were shelved together at Richmond. ${ }^{6}$ While we can assume that there was care to keep the collections distinct, we must also note the exigencies of the times. Consider in particular Oliver Beckerlegge's recent comments on his initial days as a student at Richmond College in 1946. The college had been closed during World War II, and damaged by a bomb near the end of the war. Beckerlegge was entering just after it reopened and discovered the bookcases containing the Wesley materials in some disarray. He reports being given permission to clean, dust, and 'rearrange' them.

This incident suggests the possibility that there was some mixing of the two collections. A broad intermixing was unlikely, because most books in each set have clear autographs (or initials) to indicate owners. But several books are unsigned and in a few the autographs are indistinct. The ambiguity this raises is clear in a manuscript catalog of the combined collection of 'Wesley Family books' at Richmond College that was prepared in January 1951 by two students, John H. Crouch and John P. Horner. ${ }^{8}$ The compilers group the books in sections by ownership, starting with books belonging to Charles Wesley senior, then Sarah Gwynne Wesley, then the children of Charles and Sarah, then some broader family members, and finally those belonging to John Wesley. They note that in some cases the decisions are unclear, and there is evidence of the

${ }^{4}$ See particularly item 191 below, a gift from the grandson of Charles Wesley Sr. to Thomas Jackson.

${ }^{5}$ See Thomas Jackson, Recollections of My Own Life and Times (London: Wesleyan Conference Office, 1874), 230-31, 481-82, 507.

${ }^{6} \mathrm{Cf}$. C. Ryder Smith, 'The Richmond Wesleyana', Proceedings of the Wesley Historical Society 31 (1937-38): 57-60.

${ }^{7}$ See Oliver A. Beckerlegge, The Shorthand of Charles Wesley (Madison, NJ: Charles Wesley Society, 2002), 1.

${ }^{8}$ This catalog now sits (uncatalogued) beside volume 430 of the Charles Wesley family collection in the MARC. 
correcting of earlier entries as the work progressed. There is also evidence of a later hand altering some of the suggested classifications.

The later altering was likely related to the fate of the collection after Richmond College closed in 1972. The collection was initially moved to the Methodist Archives in the basement of the Epworth Press building in London. Then, after four years of considering options, it was decided to return to City Road Chapel in London those books originally taken from there - the ones that would have belonged to John Wesley. The rest were sent, along with much of the Methodist Archives, to The John Rylands University Library, as the Charles Wesley family collection. The division between the two collections was guided by John Bowmer and may be considered broadly reliable. ${ }^{9}$ It should be noted, however, that there are now two books at City Road that bear Charles Wesley's inscription. ${ }^{10}$ Likewise, there is one volume now in the Rylands collection that has John Wesley's autograph, and a few with inscriptions in John's hand. ${ }^{11}$ There are also a couple of volumes in the Rylands collection, without autographs, that other considerations would suggest were originally part of John's library. ${ }^{12}$

This brings us back to the books on Charles Wesley's manuscript lists that were not present in the original family collection donated to the Rylands. Where might they be? In addition to one of the volumes at City Road, two have been present for some time in other parts of the Methodist collection at the Rylands, one in the Wesley Historical Society Library now at Oxford Brookes University, and another in the library archives of Kingswood School. ${ }^{13}$ There is also a reported copy of the Book of Common Prayer in Greek with Charles's inscription that was given to his preparatory school (St. Peter's College, Westminster) in the 1940s. ${ }^{14}$ Perhaps most interesting is the recent identification and purchase of two volumes

${ }^{9}$ John Bowmer was the Methodist Church Archivist at the time.

${ }^{10}$ They are listed below, following the list of the Rylands collection, along with details of the inscription.

${ }^{11}$ See below, items 342-46.

${ }^{12}$ The two volumes $(337,340)$ donated by John Howard were surely to John, who met Howard at about the time of the publication of the second volume. Likewise, John showed an active interest in the medical writings of Friedrich Hoffmann (330-332), which do not appear on Charles's manuscript lists.

${ }^{13}$ I group these in an appendix below. I am indebted to Peter Forsaith for drawing to my attention the volume in the Wesley Historical Society Library.

${ }^{14}$ See John D. Carleton, Westminster School, a History, revised edition (London: Rupert Hart-Davis, 1965), 91. He reports that Charles inscribed this volume by putting one letter in the upper right-hand corner of successive pages to spell E LIBRIS CAROLI WESLEY HUJUSCE ECClesiae Sancti Petri Collegiatae Anno Domini One Thousand Seven Hundred and Twenty One Charles Wesley His Book Who is of SAint Peters College Westmonster (SIC) AMEN. Unfortunately, this volume does not appear to remain in the archives collection at Westminster. 
by research libraries. The Bridwell Library at Southern Methodist University added Charles's autographed copy of Leusden's Hebrew psalter in 2007, while the Rylands garnered a signed first volume of Spenser's Faerie Queene in 2008. ${ }^{15}$

Whatever volumes might come to light in the future, the Rylands collection will remain the most extensive indicator of books owned and read by Charles and Sarah Wesley and their children. The main caveat to this claim concerns their son Samuel. The collection includes only one book bearing his autograph (item 43). This reflects the strained relationship between Samuel and his father during the latter years of his father's life.

The list of the Charles Wesley family collection which follows is in the order the books are now shelved in the Rylands, which follows generally the order of the 1951 manuscript list. ${ }^{16}$ This means that books belonging to Charles senior come first. However, given the ambiguities of the original listing, some volumes belonging to Charles senior appear later in the listing. I list any autographs or inscriptions in the books immediately below the title. Charles senior's autograph has been verified with other examples of his writing. Autographs of other family members have been monitored for consistency, which helps to clarify a few cases of ambiguity between Charles senior and junior, and between Mrs. Sarah Wesley and Miss Sarah Wesley. In replicating the autographs below, I add clarifying indicators in square brackets to any ambiguous examples when the autograph style is that of the child rather than the parent.

While these four persons account for the majority of the autographs, there are some others of interest. Ten volumes belonged to Samuel Wesley junior, the older brother of John and Charles. ${ }^{17}$ These volumes do not appear in Charles's manuscript catalogues of 1757-64, and so they likely came into his possession on the death of Samuel junior's last surviving grandchild in 1774. ${ }^{18}$ Similarly, there is a volume (item 310) given to Charles's sister Martha by their uncle Matthew Wesley (brother of Samuel senior). Another volume appears to come from the family line of Charles's mother, Susannah [Annesley] Wesley. ${ }^{19}$ There are also a few

${ }^{15}$ The Spenser volume was added to the Charles Wesley family collection in the Rylands (\#430 on the list that follows). Details on the SMU volume are given in the appendix at the end of this article.

${ }^{16}$ One need simply add "MAW CW" to the number of each entry to have the Rylands shelf number for the book. For example, the first listed would be MAW CW1. A few of the volumes are bound collections of pamphlets originally published separately. In these cases the items are catalogued by the individual pamphlet names and each has its own shelf-number. I indicate this by putting the number of the bound volume in [brackets]. There will be no catalogue entry for the bound volume itself, only the individual items.

${ }^{17}$ See items 46, 279, 291, 302-306, 316-17.

${ }^{18}$ Philadelphia Maunsell (née Earle), daughter of Thomas Earle and Philadelphia [Wesley] Earle of Barnstaple.

${ }^{19}$ See item 315. It is unclear which Annesley this might be. 
volumes with signatures from Mrs. Sarah Wesley's extended family, the Gwynnes. And there is one volume (item 425) signed by Mary Wesley, John Wesley's wife.

A few explanations may be helpful in reading the inscriptions. At times, particularly during their school years, the Wesley brothers inscribed their names in Latin — thus Charles becomes 'Caroli', for example. They also frequently added abbreviated connection to their preparatory schools ('S. Petri Westmon.' for Charles) and to Christ Church, Oxford University ('Xt. Ch. Oxon'), etc. Perhaps more puzzling to readers will be the initials that all three Wesley brothers added to their signature at times: 'E.A.P.J.'. As Frank Baker has suggested, this likely stood for 'Ecclesiae Anglicanae Presbyter Juratus', or 'lawful presbyter of the Church of England'.20

Finally, I would note two manuscript volumes in the collection. Item 341 is a notebook containing a list of Adam Clarke's library and some letters of Samuel Wesley senior. Item 78 is Charles's copy of a book of letters by Mrs. Lefevre that John Wesley published after her death, but in the front of the book, in Charles's hand, is his poem eulogizing Mrs. Lefevre, dated 6 July 1756.

\footnotetext{
${ }^{20}$ Frank Baker, Representative Verse of Charles Wesley (London: Epworth, 1962), 368.
} 


\section{THE COLLECTION IN SHELF-NUMBER ORDER}

1 Schurman, Anna Maria van (1607-78): Nobiliss. virginis Annae Mariae à Schurman, Opuscula Hebraea, Graeca, Latina, Gallica. Prosaica \& metrica (Leiden: Elsevir, 1648).

'CWesley, ÆEd. Xti Alum., June 22. 1733'; 'Charles Wesley junr 1776'

The Psalms of David, and other portions of the sacred Scriptures, selected from various authors, adapted to the service of the Church of England, third edition (London: Printed and sold by Watts and Bridgewaters, 1800).

La Bible, qui est toute la Saincte Escriture du Vieil et du Nouveau Testament [Geneva Bible] (Paris: Anthoine Cellier, 1652).

'CWesley June 1758'; 'Charles Wesley junr 1776'; 'John Fletcher'

Note: This book was apparently a gift of John Fletcher, a native French speaker and close compatriot of John and Charles Wesley, who was teaching Charles the French language.

More, Henry (1614-87): Conjectura cabbalistica. Or, A conjectural essay of interpreting the minde of Moses, according to a threefold cabbala: viz. literal, philosophical, mystical, or, divinely moral (London: Printed by James Flesher, 1653).

'C. Wesley'

Bacon, Francis (1561-1626): Francisci Baconi de Verulamio Scripta in naturali et universali philosophia (Amsterdam: Ludwig Elzevir, 1653).

'CWesley 1758'; 'Charles Wesley junr 1776'

Roberti, Antonius (17th century) and Perkins, George (17th century): Clavis Homerica, reserans significationes, etymologias, derivationes, compositiones, \& dialectos omnium vocabulorum, quae in viginti quatuor libris Iliadis Homeri (necnon ferè Odysseae) continentur (London: Andreae Crook, 1656).

'Charles Wesley junr 1776'

Pascal, Blaise (1623-62): Les provinciales ou les lettres escrites par Louis de Montalte

(Cologne: Pierre de la Vallée, 1657).

'C. Wesley, E.A.P.J., Dec. 1. 1756'; 'Ex dono Revi. Amici Lindsey'; 'Charles Wesley junr 1776'

Note: The donor is almost certainly Theophilus Lindsey (1723-1808), who was chaplain to Lord Francis Huntingdon and interacted with the Wesleys in the 1750 s. 
Stillingfleet, Edward (1635-99): Irenicum. A weapon-salve for the Churches wounds, or the divine right of particular forms of church-government, second edition (London: Printed by R.I. for Henry Mortlock, 1662).

'Charles Wesley junr 1776'

Shaw, Samuel (1635-96): Immanuel. Or, A discovery of true religion. As it imports a living principle in the minds of men ... being the latter clause of The voice crying in a wilderness; or a continuation of the Angelical life (London: [s.n.], 1667).

'CWesley'

10 Simpson, Christopher (c.1605-69): A compendium of practical musick in five parts (London: Printed by William Godbid for Henry Brome, 1667).

'C. Wesley. The Gift of Mr Didsbury 1781'

11 Wotton, Henry, Sir (1568-1639): Reliquiae Wottonianae: or, A collection of lives, letters, poems; with characters of sundry personages, third edition (London: Printed by $\mathrm{T}$. Roycroft for R. Marriott, F. Tyton, et al., 1672).

'CWesley 1777 '

12 Simpson, Christopher (c.1605-69): A compendium of practical musick in five parts, third edition (London: Printed by M.C. for Henry Brome, 1678).

13 Stillingfleet, Edward (1635-99): The unreasonableness of separation: or, An impartial account of the history, nature, and pleas of the present separation from the communion of the Church of England (London: Printed by T.N. for Henry Mortlock, 1681).

'CWesley Jan. 7. 1759'; 'Charles Wesley junr 1776'

14 Hale, Matthew, Sir (1609-76): Contemplations moral and divine: in two parts, 2 vols in 1 (London: Printed for William Shrowsbury and John Leigh, 1682).

'CWesley 1764'

15 Virgil: P. Virgilii Maronis Opera, with notes by Thomas Farnaby (Amsterdam: JanssonWaesberg, 1685).

'CWesley Aug. 12. 1754'

16 Bouhours, Dominique (1628-1702): The life of St. Ignatius, founder of the Society of Jesus (London: Printed by Henry Hills, 1686).

'CWesley 1750'; 'Charles Wesley junr 1776'

[17] Collection of books and tracts bound together:

'CWesley 1753' (on title page of first item); 'Charles Wesley junr 1776' (on inside cover of the binding)

17.1 Ponet, John (1516?-56): Diallacticon viri boni et literati, de veritate, natura, atque substantia corporis et sanguinis Christi in Eucharistia (London: B. Griffin \& Sam. Keble, 1688). 
17.2 Lloyd, William (1627-1717): A reasonable defence of the Seasonable discourse ... in opposition to popery (London: Printed for H. Brome, 1674).

17.3 Gother, John (d. 1704): Reflections upon the answer to the papist mis-represented ([London: s.n., 1686]).

17.4 Freke, William (1662-1744): A dialogue by way of question and answer, concerning the Deity ([London: s.n., 1693]).

17.5 Elys, Edmund (c.1634-c.1707): Dei incarnati vindiciae. Contra varias execrabilis haeretici, Fausti Socini blasphemias, ac perniciosissimas hallucinationes (London: Samuel Smith, 1693).

17.6 Reflections on Dr. Sacheverell's answer to the articles of impeachment (London: Sold by B. Bragge, 1710).

17.7 Seller, Abednego (1646?-1705): The history of passive obedience since the Reformation ([Amsterdam: Printed for Theodore Johnson, 1689]).

17.8 Walker, George (1645?-90): A true account of the siege of London-derry (London: Printed for Robert Clavel and Ralph Simpson, 1689).

18 Cicero, Marcus Tullius: M. Tullii Ciceronis De officiis libri tres. Cato major sive de senectute. Laelius sive de amicitia (Amsterdam: Henricum Wetstenium, 1689).

'E Libris Caroli Wesley 1723'; 'Charles Wesley junr 1776'

19 Temple, William, Sir (1628-99): Observations upon the United Provinces of the Netherlands, fifth edition (London: Printed for Jacob Tonson and Awnsham Churchill, 1690).

'CWesley 1755'; 'Charles Wesley junr 1776'

Hopkins, Ezekiel (1634-90): Brotherly admonition. In several sermons on Leviticus 19.17 (London: Printed by J.D. for Nathanael Ranew, 1691).

'CWesley Dec. 18. 1734'; 'Charles Wesley junr 1776'

21 Esprit, Jacques (1611-78): The falshood of human virtue. A moral essay (London: Printed for Timothy Child, 1691).

'CWesley Nov. 22. 1760'; 'Charles Wesley junr 1776'

22 Marshall, Walter (1628-80): The gospel-mystery of sanctification, open'd in sundry practical directions, fourth edition (London: Printed for John Marshall, [1700?]).

'CWesley 1755'; 'Charles Wesley junr 1776'

23 Refuge, Eustache du (d. 1617): Arcana Aulica: or Walsingham's manual of prudential maxims, for the states-man and courtier, translated by Edward Walsingham (London: Printed for Matthew Gillyflower, 1694).

'C:W. [Jr.] purchas'd, Feby. 26th. 1801' 
Bull, George (1634-1710): Judicium ecclesiae Catholicae trium primorum seculorum, de necessitate credendi quod Dominus noster Jesus Christus sit verus Deus (Oxford: Sheldonian Theatre, 1694).

'CWesley 1758'; 'Charles Wesley junr 1776'

25 Tillotson, John (1630-94): Of sincerity and constancy in the faith and profession of the true religion, in several sermons (London: Printed for Ri. Chiswell, 1695).

'CWesley'

26 South, Robert (1634-1716): Twelve sermons upon several subjects and occasions, Vol. 3 (London: Printed by Tho. Warren for Thomas Bennet, 1698).

'CWesley Xt. Ch. Oxon.'

27 South, Robert (1634-1716): Twelve sermons preached at several times, and upon several occasions, Vol. 4 (London: Printed by G. James for Jonah Bowyer, 1715).

'Charles Wesley'

28 South, Robert (1634-1716): Twelve sermons and discourses on several subjects and occasions, Vol. 6 (London: Printed for Jonah Bowyer, 1717).

'Cha. Wesley Xt. Ch. Oxon.'

Collier, Jeremy (1650-1726): A short view of the immorality and profaneness of the English stage: together with the sense of antiquity upon this argument, third edition (London: Printed for S. Keble, R. Sare and H. Hindmarsh, 1698).

'CWesley Feb. 1. 1759'; 'Charles Wesley junr 1775'

30 Cervantes Saavedra, Miguel de (1547-1616): Histoire de l'admirable Don Quixotte de la Manche, Vol. 5 (Amsterdam: Pierre Mortier, 1699).

'Ch: Wesley [Jr.]'

31 Cervantes Saavedra, Miguel de (1547-1616): Histoire de l'admirable Don Quixotte de la Manche, Vol. 2 (Amsterdam: Pierre Mortier, 1700).

'Ch: Wesley [Jr.]'

32 Sherlock, Richard (1612-89): The practical Christian: or, The devout penitent. A book of devotion, containing the whole duty of a Christian, in all occasions and necessities, fifth edition (London: Printed by J.L. for Luke Meredith, 1699).

'Charles Wesley'

33 Quesnel, Pasquier (1634-1719): [Le Nouveau Testament en françois, Vol. 5:] Abregé de la morale des Actes des Apostres, et des epistres de S. Paul, new edition (Brussels: Eugene Henry Fricx, 1700).

'C. Wesley July 1. 1762'; 'Charles Wesley junr 1776' 
34 Wesley, Samuel, Sr. (1662-1735): The pious communicant rightly prepar'd; or, A discourse concerning the blessed sacrament: wherein the nature of it is described, our obligation to frequent communion enforced, and directions given for due preparation for it, behaviour at, and after it, and profiting by it. With prayers and hymns, suited to the several parts of that holy office. To which is added, a short discourse of baptism (London: Printed for Charles Harper, 1700).

'CWesley Aug. 12. 1754'

35 Floyer, John, Sir (1649-1734): The ancient [psychrolousia] [Greek] revived: or, An essay to prove cold bathing both safe and useful ... Also a letter of Dr. [Edward] Baynard's, containing an account of many eminent cures done by the cold baths in England (London: Printed for Sam. Smith and Benj. Walford, 1702).

'CWesley Aug. 12. 1754'; 'Charles Wesley junr 1776'

36.1 Fabricius, Johann Albert (1668-1736): Joh. Alberti Fabricii Bibliotheca Latina sive notitia autorum veterum Latinorum quorumcunque scripta ad nos pervenerunt (London: T. Leigh \& D. Midwinter, 1703).

'CWesley 1758'; 'CWesley junr 1776'

36.2 Marinus (5th century): Procli philosophi Platonici vita, scriptore Marino Neapolitano (London: T. Hodgkin for T. Leigh \& D. Midwinter, 1703) (original binding with preceding item).

Fuller, Francis (1670-1706): Medicina gymnastica: or, A treatise concerning the power of exercise, with respect to the animal oeconomy; and the great necessity of it in the cure of several distempers (London: Printed by John Matthews for Robert Knaplock, 1705).

'Charles Wesley junr 1776'

38 Mather, Samuel (1626-71): The figures or types of the Old Testament, by which Christ and the heavenly things of the gospel were preached and shadowed to the people of God of old. Explain'd and improv'd in sundry sermons, second edition (London: Printed for Nath. Hillier, 1705).

'CWesley 1764'; 'Charles Wesley junr 1776'

39 Beveridge, William (1637-1708): The great necessity and advantage of publick prayer and frequent communion. Designed to revive primitive piety, second edition (London: Printed by W.S. for R. Smith, 1709).

Homer: [Homērou Ilias. Ek theatrou en Oxonia] [Greek] (London: J. Bowyer \& H. Clements, 1714).

'CWesley Aug. 12. 1754'; 'Charles Wesley junr 1776' 
41.1 Hale, Matthew, Sir (1609-76): The history of the common law of England. Divided into twelve chapters, second edition ([London]: Printed by E. Nutt, 1716).

'C: Wesley'

41.2 Hale, Matthew, Sir (1609-76): The analysis of the law: being a scheme, or, abstract, of the several titles and partitions of the law of England, digested into method, second edition ([London]: Printed by E. Nutt), 1716 (original binding with preceding item).

42 Sclater, William (1638-1717?): An original draught of the primitive church: in answer to a discourse [by Peter King] entituled, An enquiry into the constitution, discipline, unity, and worship, of the primitive church (London: Printed for Geo. Strahan and J. Bowyer, 1717).

'Car[oli] Wesley, olim ex Ædi Christi Alumnus, E.A.P.J., 1785'

43 Church of England: Le Livre des Prieres Communes, et de l'administration des sacremens/The Book of Common Prayer, and administration of the sacraments, French/English version (Oxford: Printed by John Baskett, 1717).

'CWesley Oct. 27. 1766'; 'Samuel Wesley Oct. 1. 1782'

Note: This would be Samuel Wesley (1766-1837), Charles's son.

44 Fénelon, François de Salignac de La Mothe- (1651-1715): Dialogues sur l'eloquence en general, et sur celle de la chaire en particulier (Amsterdam: J.F. Bernard, 1718).

'CWesley 1765'; 'Charles Wesley junr 1776'

45 Epictetus: Epictetus his morals, with Simplicius his comment, translated by George Stanhope, fourth edition (London: Printed by W.B. [i.e. William Bowyer] for Richard Sare, 1721).

'CWesley 1756'; 'Charles Wesley junr 1776'

46 Knight, James (1672-1735): Eight sermons preached at the cathedral church of St. Paul ... at the lecture founded by the Honoured Lady Moyer (London: Printed for R. and J.

Bonwicke, and W. and J. Innys, 1721).

'E Libris Samuelis Wesley [Jr.], E.A.P.J., 1726’; 'E Libris C[arol]i. Wesley, Æd.

Xti Oxon: Alumni, ex dono Fratris Aug. 4 1732'; 'Charles Wesley junr 1776'

47.1 Homer: [Homērou Ilias] [Greek], Vol. 2 (London: Jacob Tonson \& John Watts, 1722).

'CWesley 1759'; 'Charles Wesley junr 1776'

47.2 Homer: Homeri Iliadis interpretatio Latina, Vol. 2 [Latin translation of the Greek volume above, bound together] (London: Jacob Tonson \& John Watts, 1721). 
48-49 Atterbury, Francis (1662-1732): Sermons and discourses on several subjects and occasions, 2 vols (London: Printed by S. Aris for Jonah Bowyer, 1723).

'CWesley 1725, Col. S. Petri Westmon.'; 'Charles Wesley junr 1776'

50 Leslie, Charles (1650-1722): A short and easie method with the deists. Wherein the certainty of the Christian religion is demonstrated, by infallible proof from four rules, eighth edition (London: Printed by J. Applebee, 1723).

'CWesley 1747'; 'Charles Wesley junr 1776'

51 Wright, Samuel (1683-1746): A treatise of that being born again without which no man can be saved, tenth edition (London: Printed for J. Clark and R. Hett, and E. Matthews, 1727).

'CWesley'

52 Ramsay, Andrew Michael (1686-1743): Les voyages de Cyrus, avec un discours sur la mythologie, 2 vols in 1 (Paris: André Chevalier, 1728).

'CWesley Feb. 24. 1762'; 'Charles Wesley junr 1776'

53 Ramsay, Andrew Michael (1686-1743): Histoire de la vie et des ouvrages de Messire François de Salignac de la Mothe-Fenelon, archevêque duc de Cambray (Amsterdam: François L'Honoré, 1729).

'Revd. Mr Charles Wesley [illegible] 1762' (not in Charles's hand); 'Charles Wesley junr 1776'

54 Vida, Marco Girolamo (c.1485-1566): Marci Hieronymi Vidae cremonensis Albae episcopi poemata quae extant omnia, Vol. 2 (parts 3 and 4) (London: Lawton Gilliver \& Johannis Nourse, 1732).

'E Libris Car[ol]i Wesley, Æd. Xti Oxon. Alumni, ex dono Fratris Aug. 3. 1732'

55 Bengel, Johann Albrecht (1687-1752): Io. Alberti Bengelii Ordo temporum a principio per periodos oeconomiae divinae (Stuttgart: Christoph Erhard, 1741).

'CWesley Mar. 10. 1750'; 'Charles Wesley junr 1776'

56 Law, William (1686-1761): A practical treatise upon Christian perfection, fourth edition (London: Printed for William Innys, 1741).

'Reb[ecca]. Gwynne May 1754'; 'CWesley [Jr.]. (left by his good Aunt.)'

Note: Rebecca Gwynne (1724-99) was the unmarried sister of Sarah Wesley, and lived for several years with Charles and Sarah. 
[57] Wesley, John (1703-91) and Wesley, Charles (1707-88):

[Tracts publish'd by the Rev. Mr. John and Charles Wesley, Vol. 11:] 'Charles Wesley [Jr.] March 1788'

57.1 Wesley, John (1703-91): A practical treatise on Christian perfection. Extracted from [William Law] a late author (Newcastle upon Tyne: Printed by John Gooding, $1743)$.

57.2 Wesley, John (1703-91): A serious call to a holy life. Extracted from [William Law] a late author (Newcastle upon Tyne: Printed by John Gooding, 1744).

58 Reynolds, George (1699?-1769): An historical essay upon the government of the Church of England (London: Printed for Thomas Osborne, 1743).

'CWesley Nov. 25. 1755. The Gift of the Revd. Mr Castle'

59-61 Wesley, John (1703-91): A collection of moral and sacred poems from the most celebrated English authors, 3 vols (Bristol: Printed and sold by Felix Farley, 1744).

'C \& S Wesley'

[62] Wesley, John (1703-91) and Wesley, Charles (1707-88): Tracts publish'd by the Rev. Mr. John and Charles Wesley, Vol. 8, and part of Vol. 9 (bound together):

'C. Wesley'

62.1 Wesley, John (1703-91): An answer to the Rev. Mr. Church's remarks on the Rev. Mr. John Wesley's last journal, second edition (London: Printed by W. Strahan, 1745).

62.2 Wesley, John (1703-91): The principles of a Methodist farther explain'd (London: Printed by W. Strahan, 1746).

62.3 Wesley, John (1703-91): The character of a Methodist, sixth edition (Bristol: Printed by Felix Farley, 1747).

62.4 Wesley, John (1703-91): The principles of a Methodist, second edition (Bristol: Printed by Felix Farley, 1746).

62.5 Wesley, John (1703-91): The nature, design, and general rules, of the United Societies in London, Bristol, Kingswood, and Newcastle upon Tyne, fourth edition (London: Printed by William Strahan, 1744).

62.6 Wesley, John (1703-91): Advice to the people called Methodists ([Newcastle]: Printed [by John Gooding], 1745).

62.7 Wesley, John (1703-91): Christian perfection: a sermon, second edition (Newcastle upon Tyne: Printed by John Gooding, 1743).

62.8 Wesley, John (1703-91): The doctrine of salvation, faith, and good works: extracted from the homilies of the Church of England, ninth edition (Bristol: Printed by S. and F. Farley, 1748). 
62.8 Wesley, John (1703-91): Swear not at all, saith the Lord God of heaven and earth ([London: Printed by W. Strahan, 1744?]).

62.8 Wesley, John (1703-91): A word to a drunkard ([Bristol: s.n.], 1748).

62.8 Wesley, John (1703-91): Remember the Sabbath day, to keep it holy ([London: Printed by W. Strahan, 1750?]).

62.8 Wesley, John (1703-91): A word to a freeholder, \&c. ([Bristol]: Printed [by Felix Farley], 1748).

62.8 Wesley, John (1703-91): A word to a street-walker ([Bristol]: Printed [by Felix Farley], 1748).

62.8 Wesley, John (1703-91): A word in season: or, Advice to a soldier ([Bristol: Printed by Felix Farley, 1748]).

62.9 Wesley, John (1703-91): A word to a Protestant, eighth edition (London: Printed by W. Strahan, 1745).

62.10 Wesley, John (1703-91): A word in season: or, Advice to an Englishman, eighth edition (London: Printed by W. Strahan, 1745).

62.11 Wesley, John (1703-91): The life of God in the soul of man: or, The nature and excellency of the Christian religion [by Henry Scougal], second edition (Bristol: Printed by Felix Farley, 1748).

63.1 Patten, Robert (fl. 1715): The history of the Rebellion in the year 1715, fourth edition (London: Printed for James Roberts, 1745).

63.2 Comber, Thomas (d. 1778): A vindication of the Great Revolution in England in A.D. $M D C L X X X V I I I$ (London: Printed for J. Robinson, 1758) (bound with preceding item).

63.3 Whitefield, George (1714-70): A letter from a clergyman at London to the remaining disconsolate inhabitants of Lisbon, fourth edition (London: Printed for R. Griffiths, 1756) (bound with preceding item).

63.4 Blacow, Richard (1723 or 4-1760): A letter to William King, LL.D. Principal of St. Mary Hall in Oxford (London: Printed for R. Griffiths, 1755) (bound with preceding item).

63.5 Watson, John (1725-83): The apology of thf [sic] Reverend John Watson, M.A., curate of Ripponden in Yorkshire (London: Printed for the author by J. Payne, 1755) (bound with preceding item). 
63.6 Foster, James (1697-1753): An account of the behaviour of the late Earl of Kilmarnock (London: Printed for J. Noon and A. Millar, 1746) (bound with preceding item).

63.7 Sykes, Arthur Ashley (1683 or 4-1756): An enquiry how far papists ought to be treated here as good subjects (London: Printed for J. and P. Knapton, 1746) (bound with preceding item).

64 Leighton, Robert (1611-84): Select works of Archbishop Leighton, some of which were never before printed (Edinburgh: Printed for David Wilson, 1746).

'Duke Gwynne'; 'Charles Wesley junr 1776'

Note: This would be Marmaduke Gwynne (1722-82), a brother of Sarah Gwynne Wesley.

65 Aurelius, Marcus (121-180): The commentaries of the Emperor Marcus Antoninus. Containing his maxims of science, and rules of life, translated by James Thomson (London: Printed by T. Parker, 1747).

'CWesley 1756'; 'Charles Wesley junr 1776'

66-67 Hartley, David (1705-57): Observations on man, his frame, his duty, and his expectations, 2 vols (London: Printed by S. Richardson, 1749).

'CWesley 1753'; 'To the Revd. Mr. Charles Wesley from the Author. June 26. 1753 '

68-69 Hervey, James (1714-58): Meditations and contemplations, seventh edition, 2 vols (London: Printed for John and James Rivington, and J. Leake, 1750).

'CWesley 1750' (Vol. 1); 'CWesley 1750. The Gift of the Friendly Author'; 'Sarah Wesley 1776' (Vol. 2)

70 Wesley, John (1703-91): Sermons on several occasions: in three volumes, Vol. 3 (London: Printed by W. Strahan, 1750).

71 Avison, Charles (1710-70): An essay on musical expression, second edition (London: Printed for C. Davis, 1753).

'CWesley Febr. 1769'

72 Gillies, John (1712-96): Historical collections relating to remarkable periods of the success of the Gospel, and eminent instruments employed in promoting it, Vol. 2 (Glasgow: Printed by Robert and Andrew Foulis, 1754).

'CWesley 1754'; 'Charles Wesley junr 1776'

73 Hartley, Thomas (1708-84): Sermons on various subjects: with a prefatory discourse on mistakes concerning religion, enthusiasm, experiences, \&c. (London: Printed for the author, 1754).

'CWesley April. 8. 1754. The Gift of the Friendly Author'; 'Charles Wesley junr 1776' 
74 Young, Edward (1683-1765): The centaur not fabulous. In five letters to a friend, on the life in vogue (London: Printed for A. Millar, and R. and J. Dodsley, 1755).

'CWesley Jan. 29. 1756. The Gift of Miss Molly Hotham'; 'Charles Wesley junr 1776 '

Note: Melusina ('Molly') Hotham, d. 1765, was a supporter of both the Wesley brothers and George Whitefield.

75 Adam, Thomas (1701-84): Practical lectures on the church catechism (London: Printed for C. Hitch and L. Hawes, 1755).

'CWesley 1756'; 'Charles Wesley junr 1776'

76 Wesley, John (1703-91) and Wesley, Charles (1707-88): Hymns and sacred poems, third edition (London: [s.n.], 1756).

'Charles Wesley junr 1776'

77 Wesley, John (1703-91) and Wesley, Charles (1707-88): Hymns and sacred poems, third edition (London: [s.n.], 1756).

78 [Lefevre, Mrs (d. 1756)]: Letters upon sacred subjects, by a person lately deceased (London: [s.n.], 1757).

'CWesley 1757 '

Note: This volume includes four pages of a manuscript poem on the death of Mrs Lefevre in Charles Wesley's hand, dated 'July 6 1756'.

79-90 Rapin de Thoyras, Paul (1661-1725): The history of England. Written in French by M. Rapin de Thoyras, translated by N. Tindal, fourth edition, 12 vols (London: Printed, by assignment from Mr. Knapton, for T. Osborne, et al., 1757).

'CWesley 1758'; 'Charles Wesley junr 1776'

91-98 Tindal, Nicolas (1687-1774): The continuation of Mr. Rapin's History of England; from the Revolution to the present times, fourth edition, 8 vols (London: Printed, by assignment from Mr. Knapton, for T. Osborne, et al., 1758-9).

'CWesley 1758'; 'Charles Wesley junr 1776'

99-108 Rollin, Charles (1661-1741): The ancient history of the Egyptians, Carthaginians, Assyrians, Babylonians, Medes and Persians, Macedonians, and Grecians, 10 vols (Edinburgh: Printed for Hamilton and Balfour, Kincaid and Donaldson, and W. Gray, 1758).

'CWesley July 26. 1763' (all vols); 'Sally Wesley Nov: 1788' (Vol. 1); 'Sally Wesley, the Gift of her Father, 1788' (Vols 2, 4-10); 'SWesley. left By her Father to her' (Vol. 3) 
109 Robe, James (1688-1753): A second volume of sermons, in three parts (Edinburgh: Printed by R. Fleming, 1750).

'CWesley 1750. The Gift of my much respected and beloved Friend James Erskine Esqr.'; 'Charles Wesley junr 1776'

Note: James Erskine, Lord Grange (1679-1754), was a Scottish judge who had been much affected by the Wesleys' preaching during a visit to London.

110-13 Rollin, Charles (1661-1741): The method of teaching and studying the belles lettres, fifth edition, 4 vols (Edinburgh: Printed by R. Fleming for A. Kincaid and J. Bell, et al., 1759).

'CWesley 1763' (all vols); 'Charles Wesley junr 1776' (Vol. 1 only)

114-17 Homer: The Iliad of Homer, translated by Alexander Pope, 4 vols (London: Printed for A. Horace, P. Virgil, et al., 1759).

'CWesley Sept. 24, 1765'

118-20 Homer: The Odyssey of Homer, translated by Alexander Pope, 4 vols (London: Printed for A. Horace, P. Virgil, et al., 1760) (lacking Vol. 1).

'CWesley Sept. 24, 1765'

121-4 Keyssler, Johann Georg (1693-1743): Travels through Germany, Bohemia, Hungary, Switzerland, Italy, and Lorrain, third edition, 4 vols (London: Printed for G. Keith, A. Linde, et al., 1760).

'Duke Gwynne'; 'Charles Wesley junr 1776'(both in all vols); 'The Gift of the Revnd. Charles Wesley to C.W. junior' (all except Vol. 2)

Note: See note for item 64 above.

125-26 Robertson, William (1721-93): The history of Scotland during the reigns of Queen Mary and of King James VI. till his accession to the Crown of England, fourth edition, 2 vols (London: Printed for A. Millar, 1761).

'CWesley junr 1776' (Vol. 1); 'Charles Wesley junr 1776' (Vol. 2)

127 Law, William (1686-1761): An humble, earnest, and affectionate address to the clergy (London: Printed for J. Richardson, 1761).

'CWesley 1761'; 'Charles Wesley junr 1776'

128-29 Buchanan, George (1506-82): The history of Scotland, from the earliest accounts of that nation, to the reign of King James VI., fifth edition, 2 vols (Edinburgh: Printed by A. Donaldson and J. Reid, 1762).

'Charles Wesley junr 1776' 
130 Wesley, Charles (1707-88): Short hymns on select passages of the Holy Scriptures, Vol. 2

(Bristol: Printed by E. Farley, 1762).

'Charles Wesley junr 1776'

131-33 Virgil: The works of Virgil. In English verse, translated by Christopher Pitt and Joseph Warton, 4 vols (London: Printed for R. and J. Dodsley, 1763) (lacking Vol. 3).

'Charles Wesley [Jr.]'

134 Hartley, Thomas (1708-84): Paradise restored: or a testimony to the doctrine of the blessed millennium: with some considerations on its approaching advent ... To which is added, a short defence of the mystical writers, against a late work, intitled, The doctrine of grace, or the office and operations of the Holy Spirit vindicated, \&c. (London: Printed for M. Richardson, 1764).

'Reb[ecca]: Gwynne'; 'Ch: Wesley [Jr.] (The Gift of his worthy Aunt.)' Note: See note for item 56 above.

135 Phaedrus: A poetical translation of the Fables of Phaedrus (London: Printed for J. Dodsley, 1765).

'Charles Wesley junior 1772 May' (never belonged to Charles senior)

136 Jones, William (1726-1800): The Catholic doctrine of a Trinity proved, third edition (London: Printed for J. Rivington, Robinson and Roberts, and S. Withers, 1767).

'Charles Wesley [Jr.]'

137 An introduction to the Latin tongue, for the use of youth, new edition, revised (Eton: Printed by J. Pote, 1769).

'Charles Wesley [Jr.] 1771'

138-41 Pope, Alexander (1688-1744): The works of Alexander Pope, Esq; in four volumes, complete (Edinburgh: [s.n.], 1764).

'CWesley 1764'; 'Charles Wesley junr 1776'

142.1 Wesley, John (1703-91): Primitive physick: or, An easy and natural method of curing most diseases, fifteenth edition (London: Printed by Robert Hawes, 1772).

'Charles Wesley [Jr.]. The Gift of his Uncle the Rev: J.W.'

142.2 Wesley, John (1703-91): Advices, with respect to health. Extracted from [S.A.D. Tissot] a late author (Bristol: Printed by W. Pine, 1769) (original binding with preceding item).

[143] Wesley, John (1703-91) and Wesley, Charles (1707-88): Collection of hymn pamphlets: 'C: Wesley 1777 '

143.1 Wesley, Charles (1707-88): Hymns for the nativity of Our Lord ([London: Printed by R. Hawes, c.1776]). 
143.2 Wesley, John (1703-91): Hymns for New-Year's-Day (London: Printed by R. Hawes, 1777).

143.3 Wesley, John (1703-91): Hymns for Our Lord's resurrection, sixth edition (London: Printed by R. Hawes, 1777).

143.4 Wesley, John (1703-91): Hymns for Ascension-Day (London: Printed by R. Hawes, 1775).

143.5 Wesley, John (1703-91): Hymns of petition and thanksgiving for the promise of the Father (London: Printed by R. Hawes, 1775).

143.6 Wesley, Charles (1707-88): Gloria Patri, \&c. or, Hymns to the Trinity, sixth edition (London: Printed by Robert Hawes, 1775).

143.7 Wesley, John (1703-91): Graces. Before meat ([London: Printed by R. Hawes, c.1776]).

143.8 Wesley, John (1703-91): Hymns for those that seek and those that have redemption in the blood of Jesus Christ, ninth edition (London: Printed by R. Hawes, 1776).

143.9 Wesley, John (1703-91): A collection of forms of prayer for every day in the week, sixth edition (London: Printed by R. Hawes, 1775).

143.10 Wesley, John (1703-91): Prayers for children (London: Printed by R. Hawes, 1777).

143.11 Wesley, John (1703-91): A collection of prayers for families [imperfect copy, c.1776].

144-45 Robertson, William (1721-93): The history of America, 2 vols (Dublin: Printed for Messrs. Whitestone, W. Watson, et al., 1777).

'The Gift of my Dear Reverend Father, to CWesley [Jr.]' (Vol. 1); 'CWesley' (Vol. 2)

146-82 Wesley, John (1703-91): A Christian library. Consisting of extracts from and abridgments of the choicest pieces of practical divinity, which have been publish'd in the English tongue, 50 vols (Bristol: Printed by Felix Farley, 1749-55) (lacking Vols 1, 6, 10, 13, 19, 26, 31 , $33,35,38,40,44,45)$.

'Charles and Sarah Wesley' (in a third-party hand, in Vol. 2)

[183] Book of Common Prayer, bound with Greek NT and Book of Psalms:

'CWesley'; 'Charles Wesley junr 1776'

183.1 The Book of Common Prayer [Charles II] ([s.l.: s.n., c.1658]).

183.2 [Tēs Kainēs Diathēkēs hapanta.] [Greek] Novi Testamenti libri omnes, new edition

(London: Roger Daniels, 1653). 
183.3 Sternhold, Thomas (d. 1549): The whole book of Psalmes: collected into English meeter (London: Printed for the Companie of Stationers, 1663).

184 Wesley, John (1703-91): A collection of moral and sacred poems, Vol. 2 (Bristol: Printed by Felix Farley, 1744).

'C. Wesley'

185 Allestree, Richard (1619-81): The whole duty of receiving worthily the blessed sacrament, tenth edition (London: Printed for C. Ware, C. Hitch, et al., 1758).

'Cwesley'

186 [Sefer Tehilim.] [Hebrew] Psalterii Davidis, new edition (Leiden: Ioannis Maire, 1650).

'CWesley Æd. Xti Alum, Mar 1. 1733'; 'Charles Wesley junr 1776'

187 South, Robert (1634-1716): Twelve sermons preached upon several occasions, Vol. 2 ([London: Printed by J.H. for Thomas Bennet, 1694]) (lacking pages 1-62).

'Charles Wesley junr 1776'

188 Nottingham, Heneage Finch, Earl of (1621-82): An exact and most impartial accompt of the ... trial, and judgment ... of twenty nine regicides, the murtherers of his late sacred Majesty (London: Printed for Andrew Crook and Edward Powel, 1660).

'CWesley 1755'; 'Charles Wesley junr 1776'

189 The Royal kalendar: or, Complete and correct annual register, for England, Scotland, Ireland, and America, for the year 1806 (London: Printed for J. Stockdale, [1806]).

'Charles Wesley [Jr.]'

190.1 The London kalendar: or, Court and city register, for England, Scotland, Ireland, and the colonies, for the year 1814 (London: Printed for John Stockdale, [1814]).

'Ch. Wesley [Jr.]'

190.2 Rider's British Merlin: for the year of Our Lord 1814 ... compiled for his country's benefit by Cardanus Rider (London: Printed for the Company of Stationers by Nichols, Son and Bentley, [1814]) (bound between pages viii and ix of preceding item).

190.3 New companion to the London and Royal calendars; or court and city register, for the year 1814 (London: Printed for John Stockdale, [1814]) (bound with preceding item).

191 Wesley, Charles, B.D., Cantab. (fl. 1830): A guide to syllogism, or, A manual of logic (London: Henry G. Bohn, 1832).

'To his Brother, from the Author'; '[Thomas] Jackson, junr., the gift of his obliged Friend John Wesley. Jany 7. 1835'

Note: This Charles and John are grandchildren of Charles Wesley senior, through Samuel. 
192 Horace: Q. Horatius Flaccus Scholiis sive annotationibus (Amsterdam: Ioannis Blaeu, 1650). 'C: Wesley'; 'SWesley'

Note: A letter ' $\mathrm{S}$ ' is written over the letter ' $\mathrm{C}$ ', indicating that Charles gave the book to his daughter Sally.

193 Horneck, Anthony (1641-97): The crucified Jesus, third edition ([London]: Printed for Samuel Lowndes, 1695).

'Sa: Wesley'

Note: Sarah Gwynne Wesley often abbreviated her first name as Sa.

194-97 Raleigh, Walter, Sir (1552?-1618): The general history of the world, being an abridgment of Sir Walter Raleigh. With a continuation from the best historians to the present times, 4 vols (London: Printed for A. Bell, R. Smith and J. Round, 1708).

'SWesley. Gift of Revd. Mr. Dickenson. 1787' (Vols 1 and 4)

Note: Peard Dickenson (1759-1802) was an Anglican clergyman who supported the Wesley brothers.

198-202 Addison, Joseph (1672-1719) and Steele, Richard, Sir (1672-1729), et al.: The Spectator, 8 vols (London: Printed for S. Buckley and J. Tonson, 1712-15) (lacking Vols 1, 4, 8).

'S. Wesley, the Gift of Her ever Honor'd deceas'd Friend Mrs Vigor. 1775'

(Vols 2 and 3)

203 Arndt, Johann (1555-1621): The Garden of Paradise: or, Holy prayers and exercises; whereby the Christian graces and virtues may be planted and improved in man ... Pursuing the design of the famous treatise of True Christianity, translated by Anton Wilhelm Böhm (London: Printed and sold by J. Downing, 1716).

'Sarah Wesley’s Book, Apl. 4th. 17[ ]' [rest of date cut off]

204 Ken, Thomas (1637-1711): The practice of divine love revised: being an exposition of the church-catechism (London: Printed for A. Bettesworth and C. Rivington, 1718).

'Sarah Gwynne'; 'Sarah Wesley'

205 Bisse, Thomas (d. 1731): The beauty of holiness in the Common-Prayer, seventh edition (London: Printed by W. Bowyer for W. Taylor, and W. and J. Innys, 1720).

'Sarah Gwynne's Book. given by my Bror. H:G.'

Note: This would be Howell Gwynne (1718-80), a brother of Sarah Gwynne Wesley. 
206 A companion for the grand festival of the Christian Church or the Lord's-Day (London: Printed for T. Bickerton and J. Wilford, and C. Rivington, 1721).

'Sa: Wesley'

207.1 Synge, Edward (1659-1741): Some short and plain directions for the spending of one day well; by which ... a man may be much enabled, (through God's grace) to spend his whole life well, fifth edition (London: Printed for R. Sare, 1722).

'Sarah Gwynne 1741'; 'Sa. Gwynne her Book 1742'

207.2 Synge, Edward (1659-1741): An answer to all the excuses and pretences which men ordinarily make for their not coming to the Holy Communion, twelfth edition (London: Printed for the executors of R. Sare, 1726) (bound with preceding item).

208 Ramsay, Andrew Michael (1686-1743): The life of François de Salignac de la Motte Fenelon, Archbishop and Duke of Cambray (London: Printed for Paul Vaillant and James Woodman, 1723).

'CWesley'; '[Miss] Sarah Wesley'

209 Goodman, John (1626?-90): The penitent pardon'd: or, A discourse of the nature of sin, and the efficacy of repentance, under the parable of the prodigal son, eighth edition (London: Printed for D. Brown, J. Walthoe, et al., 1724).

'Sarah Gwynne 1744'

210 Delaune, William (1659-1728): Twelve sermons upon several subjects and occasions (London: Printed for R. Williamson, 1728).

'Mrs Wesley. The Gift of Dr Turner. Dec. 5. 1782'; 'From the Library of the Rev. John Fletcher'

Note: Dr Turner was a London physician whom Charles Wesley met in 1763 and was soon consulting regularly on health care.

211.1 Nelson, Robert (1656-1715): The great duty of frequenting the Christian sacrifice, and the nature of the preparation required; with suitable devotions, tenth edition (London: Printed by W. Bowyer for J. Walthoe, R. Wilkin, et al., 1734).

'Sa: Wesley'

211.2 Church of England: The order for the administration of the Lords Supper, or Holy Communion ([Cambridge: Printed by W. Fenner, 1734]) (bound with preceding item).

212 Addison, Joseph (1672-1719) and Steele, Richard, Sir (1672-1729), et al.: The Spectator, twelfth edition, Vol. 1 (London: Printed for J. and R. Tonson, 1739).

'Miss Wesley' (not in Sarah's hand) 
[213] Wesley, John (1703-91) and Wesley, Charles (1707-88): Tracts publish'd by the Rev. Mr. John and Charles Wesley, Vol. 15:

'Sarah Wesley Oct. 12, 1749'

213.1 Wesley, John (1703-91): Free grace. A sermon preach'd at Bristol (London: Printed by W. Strahan, 1740).

213.2 Wesley, John (1703-91): A dialogue between a predestinarian and his friend, second edition (London: Printed by W. Strahan, 1741).

213.3 Wesley, John (1703-91): Serious considerations on absolute predestination. Extracted from [Robert Barclay] a late author (Bristol: Printed by S. and F. Farley, 1741).

213.4 Wesley, John (1703-91): Serious considerations concerning the doctrines of election and reprobation. Extracted from [Isaac Watts] a late author (London: Printed [by W. Strahan], 1740).

213.5 Wesley, John (1703-91): The Scripture doctrine concerning predestination, election and reprobation. Extracted from [Henry Haggar] a late author (London: Printed by W. Strahan, 1741).

213.6 Wesley, John (1703-91): Thoughts on marriage and a single life, second edition (Bristol: Printed by Felix Farley, 1743).

213.7 Wesley, John (1703-91): A short view of the difference between the Moravian Brethren, lately in England, and the Reverend Mr. John and Charles Wesley, second edition (Bristol: Printed by Felix Farley, 1748).

213.8 Wesley, John (1703-91): A dialogue between an Antinomian and his friend (London: Printed by W. Strahan, 1745).

213.9 Wesley, John (1703-91): A second dialogue between an Antinomian and his friend (London: Printed by W. Strahan, 1745).

213.10 Wesley, John (1703-91): An extract of Mr. Richard Baxter's Aphorisms of justification (Newcastle upon Tyne: Printed by John Gooding, 1745).

213.11 Wesley, John (1703-91): Primitive physick: or, An easy and natural method of curing most diseases (London: Printed and sold by Thomas Trye, 1747).

214 Addison, Joseph (1672-1719) and Steele, Richard, Sir (1672-1729), et al.: The Guardian, seventh edition, Vol. 2 (London: Printed for J. and R. Tonson, 1740).

'Sarah Gwynne's Book July ye. [the] 20th. 1747'

215 Watts, Isaac (1674-1748): Reliquiae juveniles: miscellaneous thoughts in prose and verse, on natural, moral, and divine subjects; written chiefly in younger years, third edition (London: Printed for James Brackstone, 1742).

'Sally Gwynne Her Book 1747' 
216 Whitefield, George (1714-70): Nine sermons upon the following subjects; viz. I. The Lord our righteousness ... IX. The conversion of Zaccheus (London: Printed and sold by Sam.

Mason and Gab. Harris, Jun., 1742).

'Sarah Gwynne's Book 1742'

[217] Wesley, John (1703-91) and Wesley, Charles (1707-88): Tracts publish'd by the Rev. Mr. John and Charles Wesley, Vol. 10:

'Sarah Wesley Oct. 12. 1749'

217.1 Wesley, John (1703-91): A treatise on Christian prudence. Extracted from Mr. [John] Norris, second edition (London: Printed by W. Strahan, 1742).

217.2 Wesley, John (1703-91): Reflections upon the conduct of human life: with reference to learning and knowledge. Extracted from Mr. [John] Norris, second edition (London: Printed by W. Strahan, 1741).

217.3 Wesley, John (1703-91): Instructions for children, third edition ([London]: Printed for M. Cooper, 1747).

217.4 Wesley, John (1703-91): An extract of the Christian's pattern: or, A treatise of the imitation of Christ. Written in Latin by Thomas a Kempis (Bristol: Printed and sold by Felix Farley, 1746).

217.5 Wesley, John (1703-91): Extract of Count Zinzendorf's Discourses on the redemption of man by the death of Christ (Newcastle on Tyne: Printed by John Gooding, 1744).

[218] Wesley, John (1703-91) and Wesley, Charles (1707-88): Tracts publish'd by the Rev. Mr. John and Charles Wesley, Vol. 11:

'Sarah Wesley Oct. 12. 1749'

218.1 Wesley, John (1703-91): A practical treatise on Christian perfection. Extracted from [William Law] a late author (Newcastle upon Tyne: Printed by John Gooding, 1743).

218.2 Wesley, John (1703-91): A serious call to a holy life. Extracted from [William Law] a late author (Newcastle upon Tyne: Printed by John Gooding, 1744).

219 Wesley, John (1703-91) and Wesley, Charles (1707-88): Hymns and sacred poems, fourth edition, Vol. 1 (Bristol: Printed by Felix Farley, 1743).

'Sarah Wesley Oct. 12. 1749'

220 Wesley, John (1703-91) and Wesley, Charles (1707-88): Hymns and sacred poems, second edition, Vol. 2 (Bristol: Printed by Felix Farley, 1745).

'Sarah Wesley Oct. 12. 1749'

221 Wesley, John (1703-91): A collection of moral and sacred poems, Vol. 3 (Bristol: Printed by Felix Farley, 1744).

'Sarah Wesley April 1. 1769' 
[222] Wesley, John (1703-91) and Wesley, Charles (1707-88): Tracts publish'd by the Rev. Mr. John and Charles Wesley, Vol. 14:

'Sarah Wesley Oct. 12. 1749'

222.1 Wesley, John (1703-91): An earnest appeal to men of reason and religion, third edition (Bristol: Printed by Felix Farley, 1744).

222.2 Wesley, John (1703-91): A farther appeal to men of reason and religion, Part 1 (London: Printed by W. Strahan, 1745).

222.3 Wesley, John (1703-91): A farther appeal to men of reason and religion, fourth edition, Parts 2 and 3 (London: Printed by W. Strahan, 1746).

[223] Wesley, John (1703-91) and Wesley, Charles (1707-88): Collected publications: 'Sarah Wesley Oct. 12. 1749'

223.1 Wesley, John (1703-91): An extract of the Revd. Mr. John Wesley's journal, from Sept. 3, 1741. to October 27, 1743. (Bristol: Printed by Felix Farley, 1749).

223.2 Wesley, John (1703-91): A letter to the Reverend Doctor Conyers Middleton, second edition (Bristol: Printed by Felix Farley, 1749).

223.3 Wesley, John (1703-91): A letter to the Right Reverend the Lord Bishop of London (London: Printed by W. Strahan, 1747).

223.4 Wesley, John (1703-91): A plain account of the people called Methodists, second edition (London: Printed by W. Strahan, 1749).

223.5 Wesley, John (1703-91): The manners of the antient Christians. Extracted from [Claude Fleury] a French author (Bristol: Printed by Felix Farley, 1749).

224 Wesley, John (1703-91): A collection of moral and sacred poems, Vol. 3 (Bristol: Printed by Felix Farley, 1744).

'S[arah]:G[wynne]'

225 Arndt, Johann (1555-1621): True Christianity. Volume II. Compleating the whole oeconomy of God towards man; and the whole duty of man towards God, second edition (London:

Printed and sold by M. Downing, 1744).

'Sarah Wesley's Book Apl. 4th. 1751'

226 Bailey, Nathan (d. 1742): An universal etymological English dictionary (London: Printed for R. Ware, A. Ward, et al., 1747).

'S[arah]:G[wynne]'; 'Sarah Wesley'

227 Gauden, John (1605-62): [Eikon basilike.] [Greek] The pourtraicture of his sacred Majestie in his solitudes and sufferings ([London: Printed by H. Hills], 1649).

'I borrow'd this book of Mrs. James of Earl's-Mead. 1757' (appears to be in Mrs Sarah Wesley's hand); 'Sarah Wesley. 1769'

Note: Sally James of Earl's Mead, Bristol, was a long-time friend of the Wesleys. 
228 Law, William (1686-1761): A serious call to a devout and holy life. Adapted to the state and condition of all orders of Christians, fifth edition (London: Printed for W. Innys, 1750). 'Sarah Wesley'

229 Wesley, John (1703-91): Sermons on several occasions: in three volumes, Vol. 3 (London: Printed by W. Strahan, 1750).

[230] Wesley, John (1703-91) and Wesley, Charles (1707-88): Collected hymns and tracts:

'Sa: Wesley 1750'

Note: The last two items are now bound separately because they came loose.

230.1 Wesley, John (1703-91): Hymns for the nativity of Our Lord ([London: Printed by W. Strahan, 1744]).

230.2 Wesley, John (1703-91): Hymns for Our Lord's resurrection, third edition (Bristol: Printed by Felix Farley, 1748).

230.3 Wesley, John (1703-91): Hymns for Ascension-Day, second edition (Bristol: Printed by Felix Farley, 1747).

230.4 Wesley, John (1703-91): Hymns of petition and thanksgiving for the promise of the Father, second edition (Bristol: Printed by Felix Farley, 1747).

230.5 Wesley, John (1703-91): Hymns for those that seek and those that have redemption in the blood of Jesus Christ, third edition (Bristol: Printed by Felix Farley, 1751).

230.6 Wesley, John (1703-91): Funeral hymns, second edition ([London: Printed by W. Strahan, 1746]).

230.7 Wesley, John (1703-91): Graces, before meat ([London: Printed by R. Hawes, 1777?]).

230.8 Wesley, Charles (1707-88): Gloria patri, \&c. or, Hymns to the Trinity, second edition (Bristol: Printed by Felix Farley, 1749).

230.9 Wesley, John (1703-91): Hymns for times of trouble and persecution, second edition (London: 1744; reprinted at Bristol: Felix Farley, 1745).

230.10 Wesley, John (1703-91): Hymns for times of trouble ([London: Printed by W. Strahan], 1745).

230.11 Wesley, John (1703-91): Hymns for the public thanksgiving-day, October 9, 1746

([Bristol]: Printed [by Felix Farley], 1746). 
230.12 Wesley, John (1703-91): Hymns for New-Year's-Day. M.DCC.L (Bristol: Printed by Felix Farley, [1750]).

230.13 Wesley, John (1703-91): Hymns occasioned by the earthquake, March 8, 1750, second edition (London: Printed [by W. Strahan], 1750).

231 Ken, Thomas (1637-1711): The retired Christian exercised in divine thoughts, and heavenly meditations, for the closet, sixth edition (London: Printed for T. Astley, 1750).

'Sarah Wesley Dec. 18. 1754'

232.1 Rimius, Henry (d. c.1757): A candid narrative of the rise and progress of the Herrnhuters, commonly call'd Moravians or Unitas Fratrum (London: Printed for A. Linde, 1753).

'CWesley 1753'

232.2 Rimius, Henry (d. c.1757): A solemn call on Count Zinzendorf, the author, and advocate of the sect of Herrnhuters ... to answer all and every charge brought against them in the Candid narrative \&c (London: Printed for A. Linde, 1754) (bound with preceding item).

232.3 Rimius, Henry (d. c.1757): A supplement to the Candid narrative of the rise and progress of the Herrnhuters (London: Printed for A. Linde, 1755) (bound with preceding item).

233-35 Hervey, James (1714-58): Theron and Aspasio: or, A series of dialogues and letters, upon the most important and interesting subjects, 3 vols (London: Printed for John and James Rivington, 1755).

'Sarah Wesley' (all vols); ‘Sarah Wesley 1756. Jan. 29. The Gift of Miss Molly Hotham' (Vols 2 and 3)

Note: See note for item 74 above.

236 Whitefield, George (1714-70): A communion morning's companion (London: Printed by W. Strahan, 1755).

'Sa: Wesley'

237 Romaine, William (1714-95): Twelve discourses upon some practical parts of Solomon's Song (London: Printed for J. Worrall and E. Withers, 1758).

'Sa: Wesley July 8 th 1758 '

238 Romaine, William (1714-95): Twelve discourses upon the law and the Gospel (London: Printed for J. Worrall and M. Withers, 1760).

'Sarah Wesley, the Gift of Miss Gidson, Aug. 6. 1763'

239 Church of England: The Book of Common Prayer, and administration of the sacraments ... together with the Psalter, or Psalms of David (London: Printed by Mark Baskett, 1763). '[Miss] Sarah Wesley Novr. 2d 1795' 
240 Allestree, Richard (1619-81): The ladies calling in two parts, fifth impression (Oxford: At the [Sheldonian] Theater, 1677).

'S: Wesley Bo[ugh]t. in Bristol Sepr. 1787'

241 Beaulieu, Luke de (1644 or 5-1723): Claustrum animae: the reformed monastery; or, The love of Jesus (London: Printed for Henry Brome, 1677).

'Sa: Wesley'

242-43 Cennick, John (1718-55): Twenty discourses, 2 vols [i.e. 40 discourses] (London: Printed and sold by H. Trapp, 1777).

'S: Wesley. Bo[ugh]t. in Bristol 7br. [September] 1787' (Vol. 1)

244-66 Wesley, John (1703-91): The Arminian Magazine, Vols 1-24 (1778-1801) (lacking Vol. 10). '[Miss] Sarah Wesley 10 Vols.'; '(The Gift of her Father.) Confirm'd by CW. Junr' (latter written in by a third party) (Vol. 1)

Note: Various autographs in Vols 11-24 inclusive indicate that these were a gift from Mr James Kenton, from 1788 to 1802.

267 Duché, Jacob (1738-98): Discourses on various subjects, second edition, Vol. 2 (London: Printed by J. Phillips, 1780).

'Sarah Wesley'

268-71 Wesley, John (1703-91): A concise ecclesiastical history, from the birth of Christ, to the beginning of the present century [abridged translation of Johann Lorenz von Mosheim's Institutiones historiae Christianae], 4 vols (London: Printed by J. Paramore, 1781).

'SWesley. The Gift of the Revd. Mr John Wesley. 1786. Nov:'

272 Berkeley, Ann (18th century): The contrast; or, An antidote against the pernicious principles disseminated in the letters of the late Earl of Chesterfield, edited by Sir Adam Gordon (London: Printed for John Stockdale, 1791).

'SWesley. The Gift of its worthy Author. Rev Sir Adam Gordon. Sept 27. 1863 $[$ sic $]$ '

273 Hunter, Henry (1741-1802): Sermons, and other miscellaneous pieces ... in two volumes, Vol. 2 (London: Printed for J. Murray, et al., 1804).

'SWesley. The Gift of her invaluable Friend Mr Cowie Jan: 14. 1805'

274 Quesnel, Pasquier (1634-1719): Le Nouveau Testament en françois, avec des reflexions morales sur chaque verset, Vol. 3 (Brussels: Eugene Henry Fricx, 1702).

'Charles Wesley junr 1776'; '[Miss] Sally Wesley. The Gift of Charles Wesley junr' 
275-76 Terence: Les comedies de Terence; avec la traduction et les remarques de Madame Dacier, new edition, 3 vols (Hamburg: A. Vandenhoeck, 1732) (lacking Vol. 2).

'Miss Wesley. 1780'

277 Wesley, John (1703-91) and Wesley, Charles (1707-88): Hymns and sacred poems, Vol. 2 (Bristol: Printed and sold by Felix Farley, 1749).

'Marg[aret]. \& Elis[abeth]. Gwynne at Bristol Sept. 1. 1749'; 'Left by Aunt Gwynne to Miss S: Wesley. Augst. 28th 1789'

Note: Elisabeth Gwynne (b. 1730) and Margaret Gwynne (1733-52) were younger sisters of Sarah Gwynne Wesley.

278 An introduction to the Latin tongue, for the use of youth, new edition, revised (Eton: Printed by J. Pote, 1771).

'Charles Wesley to [Miss] SWesley June 17th. 1774'

279 Terence: Publius Terentius Afer [his comedies] (Saumur: René Pean, 1671).

'Samuel Wesley [Jr.]'; 'Revnd. C: Wesley, Xt. Ch. Oxon.'; 'CWesley 1757';

'Charles Wesley junr 1776'; '[Miss] Sarah Wesley. The Gift of her Brother Charles'

280 Cumberland, Richard (1732-1811): The Observer (London: Printed for C. Dilly, 1785).

281 Matthews, William (fl. 1785): The miscellaneous companions, Vol. 1 (Bath: Printed for the author by R. Cruttwell, 1786).

'Miss Wesley when at Bath'; 'From the Author W.M. of the Society of Friends'

282 Plutarch: Plutarch's morals: translated from the Greek by several hands, third edition, Vol. 1 (London: Printed by Tho. Braddyll, 1694).

'Miss Wesley. The Gift of the worthy Rev: J. Fountains'

Note: This is almost certainly the gift of John Fountain (1706-87), who was a fellow student with Charles Wesley at Christ Church, Oxford.

283 Lowell, Samuel (1759-1823): Sermons, on evangelical and practical subjects, designed chiefly for the use of families (Bristol: Printed by Biggs \& Cottle for the author, 1801).

'Miss Wesley. The Gift of J. Cowie Esqu. of Highbury Grove'

284 Foster, John (1770-1843): Essays in a series of letters to a friend, Vol. 2 (London: Printed for Longman, etc., 1805).

'SWesley. Bath June 1806' 
285 Myles, William (1756-1828): A chronological history of the people called Methodists, fourth edition (London: Printed by Thomas Cordeux, 1813).

'SWesley, the Gift of its respected Author Mr Myles, March 3. 1814'

Note: William Myles was an Irish Methodist who was converted by John Wesley in 1773.

286 Vincent, John (fl. 1810-15): Sermons on practical subjects (London: Printed for F.C. and J. Rivington, 1814).

'Mr. Charles [Jr.] and Mrs. Sarah Wesley' (in a third-party hand)

287 Simon, Richard (1638-1712): A critical history of the Old Testament (London: Printed for Jacob Tonson, 1682).

'Thomas Saunders. His Book June 10th 1795'

288 Burnet, Gilbert (1643-1715): A collection of eighteen papers, relating to the affairs of Church \& State (London: Reprinted for John Starkey and Richard Chiswell, 1689).

289 Baxter, Richard (1615-91): A treatise of knowledge and love compared (London: Printed for Tho. Parkhurst, 1689).

290 Plutarch: Plutarch's morals: translated from the Greek by several hands, third edition, Vol. 2 (London: Printed by Tho. Braddyll, 1694).

291 Bentley, Richard (1662-1742): The folly and unreasonableness of atheism, fourth edition (London: Printed by J.H. for H. Mortlock, 1699). 'E Libris Samuelis Wesley. S.R.W.A. 1711'

Note: This inscription is dated the year that Samuel Wesley junior graduated from Westminster and headed to Christ Church. The initials at the end likely express this alumnus status.

292 Welwood, James (1652-1727): Memoirs of the most material transactions in England, for the last hundred years, preceding the Revolution in 1688 (London: Printed for Tim. Goodwin, 1700).

293 Jurieu, Pierre (1637-1713): A critical history of the doctrines and worships (both good and evil) of the Church from Adam to our saviour Jesus Christ. Giving an account of the origin of all the idolatries of the ancient pagans, as far as they relate to the Jewish worship, Vol. 2 (London: Printed for J. Taylor and G. Sawbridge, 1705).

294-99 Clarendon, Edward Hyde, Earl of (1609-74): The history of the Rebellion and civil wars in England, begun in the year 1641, 3 vols, each in 2 parts (Oxford: Printed at the [Sheldonian] Theater, 1707). 
$300.1 \quad$ Sacheverell, Henry (1674-1724): The tryal of Dr. Henry Sacheverell, before the House of Peers, for high crimes and misdemeanors (London: Printed for Jacob Tonson, 1710).

300.2 Burnet, Gilbert (1634-1715), et al.: The Bishop of Salisbury's, and the Bishop of Oxford's speeches in the House of Lords, on the ... impeachment of Dr. Henry Sacheverell; also the Bishop of Lincoln's and Bishop of Norwich's speeches (London: Printed and sold by John Morphew, 1710) (bound with preceding item).

301 King, Peter (1669-1734): An enquiry into the constitution, discipline, unity \& worship, of the primitive church ([London?: s.n.], 1712).

302 Church of England: A collection of articles, canons, injunctions, \&c. (London: Printed by John Baskett, 1713).

'E Libris Samuelis Wesley. Ædis Christi Oxon. Alumn. 1716'

303-305 Bull, George (1634-1710): Some important points of primitive Christianity maintained and defended; in several sermons and other discourses, second edition, 3 vols (London: Printed for Richard Smith, 1714).

'E Libris Samuelis Wesley. Æd. Xti Oxon. Alumn. 1719'

306 Nelson, Robert (1656-1715): The life of Dr. George Bull, late Lord Bishop of St. David's, second edition (London: Printed by J.L. [John Lecke?] for Richard Smith, 1714).

'E Libris Samuelis Wesley. Æd. Xti Oxon. Alumn. 1719'

307 Saunders, Richard (d. 1692): [Angelographia sive pneumata leiturgika (sic), pneumatologia] [Greek]: or, A discourse of angels: their nature and office, or ministry (London: Printed for Thomas Parkhurst, 1701).

308 Ward, Edward (1667-1731): The Lord Clarendon's history of the Grand Rebellion compleated, third edition (Dublin: Printed for J. Leathley and P. Dugan, 1720).

309 Steele, Richard, Sir (1672-1729): The Christian hero: an argument proving that no principles but those of religion are sufficient to make a great man, eighth edition (London: Printed for J. Tonson, 1727).

'E Libris Roderici Gwynne, anno Domini 1749'

Note: Roderick Gwynne (1735-70) was Sarah Gwynne Wesley’s youngest brother.

310 Berkeley, George (1685-1753): Alciphron: or, The minute philosopher, Vol. 1 (London: Printed for J. Tonson, 1732).

'Patty Wesley's Book, the Gift of Mr. Matthew Wesley'

Note: Matthew Wesley (1661-1737) is Samuel Wesley senior's brother; 'Patty' was the family name for Martha Wesley (1706-91), sister of John and Charles. 
311 Lake, Edward (1641-1704): Officium Eucharisticum. A preparatory service to a devout and worthy reception of the Lord's Supper, twenty-eighth edition (London: Printed [by Sam Aris] for T. Ward and E. Wicksteed, 1732).

'Sarah Gwynne Her Book. Bought in ye. [the] year 1741'

312 Freylinghausen, Johann Anastasius (1670-1739): Geistreiches Gesangbuch den Kern alter und neuer Lieder ... Nebst ... 1. Theil., seventeenth edition (Halle: Wäysenhauses, 1734).

313 H., D., presbyter of the Church of England: A father's advices to his children (London: Printed for the author, 1740).

[314] Wesley, John (1703-91) and Wesley, Charles (1707-88): Assorted publications:

314.1 Wesley, John (1703-91): An extract of the Revd. Mr. John Wesley's journal from August 12, 1738, to Nov. 1, 1739 (Bristol: Printed by Felix Farley, 1742).

314.2 Wesley, John (1703-91): Scriptural Christianity: a sermon preached, August, 24, 1744, fifth edition (London: Printed by W. Strahan, 1744).

314.3 Wesley, Charles (1707-88): A sermon preach'd on Sunday, April 4th, 1742, seventh edition (London: Printed by W. Strahan, 1745).

314.4 Wesley, John (1703-91): A sermon on salvation by faith, eighth edition (London: Printed by W. Strahan, 1747).

314.5 Wesley, John (1703-91): The almost Christian: a sermon preach'd at St. Mary's, Oxford, before the University, on July 25, MDCCXLI, seventh edition (Bristol: Printed by Felix Farley, 1748).

314.6 Wesley, John (1703-91): Christian perfection: a sermon, second edition (Newcastle upon Tyne: Printed by John Gooding, 1743).

314.7 Perronet, Vincent (1693-1785): Some remarks on a late anonymous piece, intitled, The enthusiasm of Methodists and papists, compared (London: Printed for J. Roberts, 1749).

314.8 Janeway, James (1636?-74): An extract of the life and death of Mr. John Janeway, Fellow of King's-College in Cambridge (London: [s.n.], 1749).

314.9 Wesley, John (1703-91): The manners of the antient Christians. Extracted from [Claude Fleury] a French author (Bristol: Printed by Felix Farley, 1749). 
314.10 Wesley, John (1703-91): A narrative of the late work of God ... in New-England. Extracted from Mr. Edwards's letter to Dr. Coleman (Bristol: Printed by Felix Farley, [1744?]).

314.11 Wesley, John (1703-91): The doctrine of salvation, faith, and good works: extracted from the homilies of the Church of England, ninth edition (Bristol: Printed by S. and F. Farley, 1748).

314.12 Wesley, John (1703-91): A letter to a friend, concerning tea (London: Printed by W. Strahan, 1748).

314.13 Wesley, John (1703-91): The nature and design of Christianity. Extracted from [William Law] a late author, fifth edition (Bristol: Printed by Felix Farley, 1746).

314.14 Wesley, John (1703-91): A plain account of the people called Methodists. In a letter to the Revd. Mr. Perronet (Bristol: Printed by Felix Farley, 1749).

314.15 Wesley, John (1703-91): A short view of the difference between the Moravian Brethren, lately in England; and the Reverend Mr. John and Charles Wesley (London: Printed by W. Strahan, 1745).

314.16 Wesley, John (1703-91): An extract of the Rev. Mr. John Wesley's journal from his embarking for Georgia. To his return to London, second edition (Bristol: Printed by Felix Farley, 1743).

314.17 Wesley, John (1703-91): An extract of the Rev. Mr. John Wesley's journal from February 1, 1737-8. To his return from Germany, second edition (Bristol: Printed by Felix Farley, 1743).

[315] Collection of sermon pamphlets:

'M: Annesley'

315.1 Comber, Thomas (1645-99): The nature and usefulness of solemn judicial swearing ... in a sermon preached July 14th, 1681 ... in York (London: Printed by Samuel Roycroft for Robert Clavell, 1682).

315.2 Dove, Henry (1640-95): A sermon preached before the Right Honorable the Lord Mayor of the City of London ... on the feast of S. Michael, 1682 (London: Printed for Benj. Tooke, 1682).

315.3 Bruce, Titus (b. 1654): Monarchy maintained. In a sermon preached at St. Anne Blackfryers (London: Printed by J.R. for Fincham Gardiner, 1682).

315.4 Lloyd, William (1627-1717): A sermon preached before their Majesties at Whitehall, on the fifth day of November, 1689 (London: Printed for Robert Clavell, 1689).

315.5 Staynoe, Thomas (d. 1708): A sermon preached before the Queen at White-Hall (London: Printed for Joseph Hindmarsh, 1690). 
315.6 Moore, John (1646-1714): Of the wisdom and goodness of Providence. Two sermons preached before the Queen, at White-Hall, on August 17, 24 MDCXC (London: Printed for W. Rogers, 1690).

315.7 Lynford, Thomas (1650-1724): A sermon concerning the worship of God in private: preached before the Queen at White-Hall. June, 7th. 1691 (London: Printed for James Adamson, 1691).

315.8 Meggott, Richard (d. 1692): A sermon preached before the Queen, at White-Hall, March 11th. 1691/2 (London: Printed for Tho. Bennet, 1692).

315.9 Lloyd, William (1627-1717): A sermon preached before her Majesty, on May 29, being the anniversary of the restauration of the King and Royal family (London: Printed for Thomas Jones, 1692).

315.10 Atterbury, Francis (1662-1732): A sermon before the Queen at White-Hall, May 29. 1692 (London: Printed for Tho. Bennet, 1692).

315.11 Gee, Edward (1657-1730): Of the improvement of time. A sermon preach'd before the Queen at White-Hall, August 7. 1692 (London: Printed for Brab. Aylmer and Sam. Smith, 1692).

315.12 Resbury, Nathanael (1643-1711): A sermon preached before the Queen at White-Hall, August 21. 1692 (London: Printed for Tho. Bennet, 1692).

315.13 Sherlock, William (1641?-1707): A sermon preached at the funeral of the Reverend Richard Meggot ... Decemb. 10th. 1692 (London: Printed for W. Rogers, 1693).

315.14 Young, Edward (1641?-1705): A sermon concerning the wisdom of fearing God; preach'd at Salisbury, on Sunday, July xxx. 1693 (London: Printed by T.W. for Walter Kettilby, 1693).

315.15 Warly, Jonas (d. 1722): A sermon preach'd before the Right Honourable the Lord Mayor of the City of London ... on Sunday, Aug. 20. 1693 (London: Printed by T.W. for Walter Kettilby, 1693).

315.16 Stephens, William (d. 1718): A sermon preached before the Right Honourable the Lord Mayor, and aldermen of the City of London ... Jan 30th. 1693/4 (London: Printed for John Lawrence and Brab. Aylmer, 1694).

315.17 Stratford, Nicholas (1633-1707): Of the reverence due to God in his publick worship. A sermon preach'd before the King \& Queen, at White-Hall, March 25, 1694 (London: Printed by Tho. Warren for Thomas Bennet, 1694).

315.18 Talbot, William (1658?-1730): The unreasonableness and mischief of atheism. A sermon preached before the Queen at White-Hall, on Friday the 30th of March, 1694 (London: Printed for Tho. Bennet, 1694). 
315.19 Moore, John (1646-1714): Of the immortality of the soul. A sermon preached before the King and Queen. At White-Hall. Upon Palm-Sunday, 1694 (London: Printed for William Rogers, 1694).

315.20 Tillotson, John (1630-94): A sermon preached before the King and Queen, at Whitehall, on Good-Friday, April 6. 1694 ([London]: Printed by Edward Jones and published by Randal Taylor, 1694).

315.21 Young, Edward (1641?-1705): The great advertisement, that a religious life is the best way to present happiness: in two sermons preach'd at White-Hall, ... Sunday, April the 15th. ... Sunday, Apr. 22. 1694 (London: Printed by Tho. Warren for Walter Kettilby, 1694).

315.22 Manningham, Thomas (1651?-1722): Of religious prudence. A sermon preach'd before the Queen at White-Hall, on Sunday, Sept. 17. 1693 (London: Printed for William Crooke, 1694).

315.23 Tenison, Thomas (1636-1715): A sermon preached at the funeral of her late Majesty Queen Mary ... upon March 5. 1694/5 (London: Printed for Ri. Chiswell, 1695).

315.24 Beveridge, William (1637-1708): A sermon concerning the excellency and usefulness of the Common Prayer. Preached ... 27th of November. 1681 (London: Printed by T. James for Richard Northcott, 1682).

315.25 Gilbert, John (d. 1722): A sermon preached at St. Andrew's Plymouth, January 30th, 1698/9 ... with a preface defending King Charles the Martyr (London: Printed by Sam. Darker for Tho. Bennet, 1699).

315.26 Bradford, Samuel (1652-1731): The qualifications requisite, towards the receiving a divine revelation. A sermon preach'd ... January the 2d. 1698/9. Being the first, for this year, of the lecture, founded by the Honourable Robert Boyle, Esq; (London: Printed for Tho. Parkhurst, 1699).

315.27 Bradford, Samuel (1652-1731): Apostate men fit objects of divine care and compassion. A sermon preach'd ... February the 6th, 1698/9. Being the second, for this year, of the lecture, founded by the Honourable Robert Boyle, Esq; (London: Printed for Tho. Parkhurst, 1699).

315.28 Bradford, Samuel (1652-1731): The nature of that salvation, which the Gospel offereth; and the method of obtaining it, by a mediator. A sermon preach'd ... March the 6th, 1698/9. Being the third, for this year, of the lecture, founded by the Honourable Robert Boyle, Esq; (London: Printed for Tho. Parkhurst, 1699). 
315.29 Bradford, Samuel (1652-1731): The excellency of the Christian revelation, as it removes the guilty fears of sinners, and their ignorance of God. A sermon preach'd ... April the 3d. 1699. Being the fourth, for this year, of the lecture, founded by the Honourable Robert Boyle, Esq; (London: Printed for Tho. Parkhurst, 1699).

315.30 Bradford, Samuel (1652-1731): The excellency of the Christian revelation, as it proposeth to us a perfect example. A sermon preach'd ... September the 4th. 1699. Being the sixth, for this year, of the lecture, founded by the Honourable Robert Boyle, Esq; (London: Printed for Tho. Parkhurst, 1699).

316-17 Bingham, Joseph (1668-1723): The works of the learned Joseph Bingham, M.A., 2 vols (London: Printed for Robert Knaplock, 1726).

'E Libris Samuelis Wesley, E.A.P.J., 1725'

Note: Now reshelved at MAW CWQ1 and Q2.

317A Downame, George (d. 1634): A treatise of justification (London: Printed by Felix Kyngston for Nicolas Bourne, 1633).

'CWesley 1740'

318 Hooker, Richard (1553?-1600): The works of Mr. Richard Hooker ... in eight books of ecclesiastical polity (London: Printed by Thomas Newcomb for Andrew Crook, 1666).

'Charles Wesley junr 1776'

Note: Now reshelved at MAW CWQ3.

319 Cruden, Alexander (1701-70): A complete concordance to the Holy Scriptures of the Old and New Testament (London: Printed for D. Midwinter, A. Bettesworth, et al., 1738).

'CWesley Aug. 8. 1750'

320-21 Chamberlain, Henry (fl. 1770): A new and compleat history and survey of the cities of London and Westminster, the Borough of Southwark, and parts adjacent (London: Printed for J. Cooke, [1770, 1777]).

'Charles Wesley junr 1776'

Note: Now reshelved at MAW CWQ4 and Q6.

322 Wesley, John (1703-91): Explanatory notes upon the New Testament (London: Printed by William Bowyer, 1755).

'SARAH WESLEY JUNE: YE. [THE] 24 1756'

Note: This is a gold embossed inscription, as would appear in a presentation volume.

323 Burrough, Edward (1634-62): The memorable works of a son of thunder and consolation [edited by Ellis Hookes] ([London: s.n.], 1672).

Note: Now reshelved at MAW CWQ5. 
324 Claude, Jean (1619-87): The Catholick doctrine of the Eucharist in all ages: in answer to what M. Arnaud ... alledges touching the belief of the Greek, Moscovite, Armenian, Jacobite, Nestorian, Coptic, Maronite, and other Eastern Churches (London: Printed for R.

Royston, 1684).

Note: Now reshelved at MAW CWQ7.

325 Mainwaring, John (d. 1807): Memoirs of the life of the late George Frederic Handel (London: Printed for R. and J. Dodsley, 1760).

'C. Wesley [Jr.] The Gift of his Revd. Father'

326 Hopkins, Ezekiel (1634-90): The works of the Right Reverend and learned Ezekiel Hopkins, third edition (London: Printed for Jonathan Robinson, Awnsham and John Churchill, et al., 1710).

Note: Now reshelved at MAW CWQ9.

327 Keiser, Reinhard (1674-1739): Songs in the opera of Croesus (London: Printed for J. Walsh, [1714]).

'The Gift of that worthy Genm. to Charles Wesley [Jr.]'

Note: This has been written on the bottom of a bookplate bearing the name 'Isaac Heaton'. Heaton is apparently the donor to Charles. Now reshelved at MAW CWQ10.

328 Cruden, Alexander (1701-70): A complete concordance to the Holy Scriptures of the Old and New Testament (London: Printed for D. Midwinter, A. Bettesworth, et al., 1738).

329 Gibson, Edmund (1669-1748): Observations upon the conduct and behaviour of a certain sect, usually distinguished by the name of Methodists, second edition (London: Printed by E. Owen, 1744).

330-32 Hoffmann, Friedrich (1660-1742): Friderici Hoffmanni consiliarii regis Borussiae intimi, et archiatri ... Opera omnia physico-medica, 6 parts in 3 (Geneva: De Tournes, 1748). Note: Now reshelved at MAW CWQ11-13.

333 Besse, Joseph (1683?-1757): A collection of the sufferings of the people called Quakers, Vol. 1 (London: Printed and sold by Luke Hinde, 1753).

Note: Now reshelved at MAW CWQ14.

334-36 Wesley, John (1703-91): Explanatory notes upon the Old Testament, 3 vols (Bristol: Printed by William Pine, 1765).

337 Howard, John (1726-90): The state of the prisons in England and Wales (Warrington: Printed by William Eyres, 1777).

'To the Revd Mr [John] Westley with Mr. Howard respects'

Note: John Howard was a prominent philanthropist and prison reformer. 
338 Cameron, Ewen (fl. 1776-77): The Fingal of Ossian, an ancient epic poem in six books (London: Printed for J. Robson, B. Law, and E. and C. Dilley, 1777).

339 Walker, Joseph Cooper (d. 1810): Historical memoirs of the Irish bards (Dublin: Printed for the author by Luke White, 1786).

340 Howard, John (1726-90): An account of the principal lazarettos in Europe; with various papers relative to the plague (Warrington: Printed by William Eyres, 1789).

'Mr Howard requests Mr: [John] Westley, will be kind enough to accept this book from him, as a small testimony of his esteem'

Note: Now reshelved at MAW CWQ15.

341 A manuscript volume, containing the list of Adam Clarke's library (published in 1833 for the sale of the library) and some letters of Samuel Wesley senior.

Note: Now reshelved at MAW CWQ16.

342 Ludovici, Christian (1660-1728): Teutsch-englishes Lexicon (Leipzig: Thomas Fritschen, 1716).

'Jwesley'

343 Wesley, John (1703-91): Thomae a Kempis De Christo imitando. Libri tres (Bristol: Printed by F. Farley, 1748).

'E Libris Josephi [illegible] Novi Castiliensis, donum Domini Johannis Wesley. 1772' (in John Wesley's hand)

344 Wesley, John (1703-91): Select hymns with tunes annexed, fourth edition (Bristol: Printed by William Pine, 1773).

Note: Volume contains corrections to tunes for new edition, in John Wesley's hand.

345 Wesley, John (1703-91): A plain account of Christian perfection (Bristol: Printed by William Pine, 1766).

'The Author's Gift to Debonair' (in John Wesley's hand)

346 Wesley, John (1703-91): A collection of moral and sacred poems from the most celebrated English authors, Vol. 1 (Bristol: Printed and sold by Felix Farley, 1744).

'January 10. 1757. Sarah Ryan' (in John Wesley's hand)

Note: John Wesley appointed Sarah Ryan as housekeeper at the school at Kingswood in 1757.

347.1 Whately, William (1583-1639): A care-cloth: or a treatise of the cumbers and troubles of marriage: intended to advise them that may, to shun them (London: Imprinted by Felix Kyngston for Thomas Man, 1624).

'CWesley Aug. 12. 1754'; 'Charles Wesley junr 1776' 
347.2 Whately, William (1583-1639): Charitable teares: or a sermon showing how needfull a thing it is for every godly man to lament the common sinnes of our countrie (London: Imprinted by Felix Kyngston for Thomas Man, 1623) (bound with preceding item).

348 Gell, Robert (1595-1665): Gell's remaines: or, Several select scriptures of the New Testament opened and explained, 2 vols in 1 (London: Printed for Nath. Brooke, 1676).

'CWesley 1742'

Note: Now reshelved at MAW CWQ8.

349 The New-Year's-gift complete. In six parts. Composed of meditations and prayers for every day in the week: with devotions for the sacrament, Lent, and other occasions (London: Printed for S. Birt and S. Harding, 1732).

'[C. Wesley] 1743 [part of text cut off]'; 'Sarah Wesley, her Book 1750'

350 Arndt, Johann (1555-1621): Of true Christianity: four books. Wherein is contained the whole oeconomy of God towards man; and the whole duty of man towards God, second edition, Part 1 (London: Printed and sold by Joseph Downing, 1720).

'Sarah Wesley's Book April 4th. 1751'

351 Nelson, Robert (1656-1715): A companion for the festivals and fasts of the Church of England, eleventh edition (London: Printed by W. Bowyer for R. Bonwick, T. Goodwin, et al., 1720).

[352] Wesley, John (1703-91): Textbooks:

'WHall 1755'; 'Westley Hall'; 'Ex dono Domini Johanni Wesley'

Note: Westley Hall (1742-57) was John Wesley’s nephew, son of his sister Martha.

352.1 Wesley, John (1703-91): Thomae a Kempis De Christo imitando. Libri tres (Bristol: Printed by F. Farley, 1748).

352.2 Wesley, John (1703-91): Caii Sallustii Crispi Bellum Catilinarium et Jugurthinum. In usum juventutis Christianae (Bristol: Printed by F. Farley, 1749).

352.3 Wesley, John (1703-91): Cornelii Nepotis excellentium imperatorum vitae. In usum juventutis Christianae (Bristol: Printed by F. Farley, 1749).

353 Wesley, John (1703-91): A Christian library: consisting of extracts from and abridgments of the choicest pieces of practical divinity, which have been publish'd in the English tongue, Vol. 10 (Bristol: Printed by Felix Farley, 1751).

354.1 Law, William (1686-1761): An extract from a serious call to a devout and holy life (Dublin: Printed for William Watson, 1762). 
354.2 Law, William (1686-1761): Extracts from the first and second parts of The spirit of prayer, and some other writers (Dublin: Printed by William Watson, 1761) (bound with preceding item).

354.3 Guyon, Jeanne Marie Bouvier de La Motte (1648-1717): Instructions from a mother to her daughter, translated from the French (Dublin: Printed for W. Watson, 1758) (bound with preceding item).

354.4 Fénelon, François de Salignac de La Mothe- (1651-1715): An extract from a discourse on humility (Dublin: Printed for W. Watson, 1758) (bound with preceding item).

354.5 Fénelon, François de Salignac de La Mothe- (1651-1715): A letter upon the truth of religion and its practice (Dublin: Printed for W. Watson, 1758) (bound with preceding item).

354.6 Fénelon, François de Salignac de La Mothe- (1651-1715): An extract from a discourse on prayer (Dublin: Printed for William Watson, 1759) (bound with preceding item).

354.7 Fénelon, François de Salignac de La Mothe- (1651-1715): A discourse upon Christian perfection (Dublin: Printed for William Watson, 1759) (bound with preceding item).

354.8 Man of quality: A letter concerning a life truly Christian. From a man of quality to his sister (Dublin: Printed for William Watson, 1759) (bound with preceding item).

354.9 The difference between a philosopher and a Christian (an appendix to 354.8, separately paginated).

355-85 Wesley, John (1703-91): The works of the Rev. John Wesley, M.A., late Fellow of LincolnCollege, Oxford, 32 vols (Bristol: Printed by William Pine, 1771-74) (lacking Vol. 8).

386-402 Wesley, John (1703-91): The works of the Rev. John Wesley, M.A., late Fellow of LincolnCollege, Oxford, 32 vols (Bristol: Printed by William Pine, 1771-74) (Vols 2-8, 11-13, $15,17,21,24,28-30$ only).

403-406 Wesley, John (1703-91): A survey of the wisdom of God in the Creation: or, A compendium of natural philosophy, third edition, 5 vols (London: Printed by J. Fry and Co., 1777) (lacking Vol. 4).

[407] Wesley, John (1703-91): Collection of Journal extracts:

407.1 Wesley, John (1703-91): An extract of the Reverend Mr. John Wesley's journal, from October 27, 1743, to November 17, 1746 (London: Printed by H. Cock, 1753).

407.2 Wesley, John (1703-91): An extract from the Reverend Mr. John Wesley's journal, from November 25, 1746, to July 20, 1750 [actually 1749] (London: Printed by H. Cock, 1754). 
407.3 Wesley, John (1703-91): An extract from the Reverend Mr. John Wesley's journal, from July 20, 1749, to October 30, 1751 (London: [s.n.], 1756).

407.4 Wesley, John (1703-91): An extract of the Reverend Mr. John Wesley's journal, from July xx, 1750, to October xxviii, 1754 (London: Printed and sold by J. Robinson and T. James, 1759) [extract actually begins at 2 November 1751].

408 The Holy Bible, containing the Old Testament and the New (Cambridge: Printed by John Archdeacon, 1769).

409.1 Wesley, John (1703-91): A sermon preached at St. Matthew's, Bethnal-Green, on Sunday, Nov. 12, 1775 (London: Printed by R. Hawes, [1775]).

'Ch: Wesley [Jr.]'

409.2 Scott, Thomas (1747-1821): The doctrines of election, and final perseverance stated from Scripture ... A sermon preached at the Lock Chapel, November 26th, 1786, third edition (London: Printed by Jaques and Thomas, 1798) (bound with preceding item).

409.3 Wesley, Charles (1707-88): The Protestant Association, written in the midst of the tumults, June 1780 (London: Printed by J. Paramore, 1781) (bound with preceding item).

409.4 Scott, Thomas (1747-1821): A discourse upon repentance, second edition (London: Printed for J. Johnson and J. Matthews, 1786) (bound with preceding item).

410-14 Wesley, John (1703-91): A survey of the wisdom of God in the Creation: or, A compendium of natural philosophy, third edition, 5 vols (London: Printed by J. Fry and Co., 1777).

[415] Wesley, John (1703-91): Collection of grammars:

415.1 Wesley, John (1703-91): A short English grammar, third edition (London: Printed by R. Hawes, 1778).

415.2 Wesley, John (1703-91): A short Latin grammar, third edition (London: Printed by R. Hawes, 1775).

415.3 Wesley, John (1703-91): A short Greek grammar (London: Printed by W.B. [i.e. William Bowyer], 1765).

415.4 Wesley, John (1703-91): A short Hebrew grammar (London: Printed by W. Bowyer and J. Nichols, 1769).

415.5 Wesley, John (1703-91): Directions concerning pronunciation and gesture (Bristol: Printed by William Pine, 1770).

415.6 Wesley, John (1703-91): A short account of the school, in Kingswood, near Bristol (Bristol: Printed by William Pine, 1768). 
416 Wesley, John (1703-91): A collection of hymns, for the use of the people called Methodists (London: Printed by J. Paramore, 1780).

417 Boston, Thomas (1677-1732): Crook in the lot; or the sovereignty and wisdom of God displayed in the afflictions of men, new edition (London: Printed for J. Mathews, 1782).

418 Simmler, Josias (1530-76): La république des Suisses, 2 vols in 1 ([Geneva: Antoine Chupin \& François Le Preux, 1577]).

'Vin: Perronet'

Note: Vincent Perronet (1693-1785) was an Anglican priest of French-Swiss descent, vicar of Shoreham and close confidant of Charles Wesley.

419 Wesley, John (1703-91) and Wesley, Charles (1707-88): Hymns and sacred poems (London: Printed by William Strahan, 1739).

420.1 Wesleyan Methodist Church: The Sunday service of the Methodists; with other occasional services, fourth edition (London: [s.n.], 1792).

420.2 Wesley, John (1703-91): A collection of Psalms and hymns for the Lord's Day (London: [s.n.], 1791) (bound with preceding item).

421 Wesley, John (1703-91): Sacred harmony, or a choice collection of Psalms and hymns, set to music ([London: s.n., 1780]).

422 Wesley, Samuel, Sr. (1662-1735): Maggots: or, Poems on several subjects, never before handled (London: Printed for John Dunton, 1685).

'by Sam. Wesley, Father to the present John Wesley'

423 Wesley, John (1703-91): A plain account of Christian perfection (Bristol: Printed by William Pine, 1766).

'[Miss] Sarah Wesley [Jr.] 1776'

[424] Wesley, John (1703-91) and Wesley, Charles (1707-88): Collection of hymn pamphlets:

'Sarah Wesley January 25 1786'

424.1 Wesley, Charles (1707-88): Hymns for the nativity of Our Lord ([London: Printed by R. Hawes, c.1776]).

424.2 Wesley, John (1703-91): Hymns for New-Year's-Day (London: Printed by J. Paramore, 1785).

424.3 Wesley, John (1703-91): Hymns for Our Lord's resurrection, sixth edition (London: Printed by R. Hawes, 1777).

424.4 Wesley, John (1703-91): Hymns for Ascension-Day (London: Printed by J. Paramore, 1784). 
424.5 Wesley, John (1703-91): Hymns of petition and thanksgiving for the promise of the Father (London: Printed by R. Hawes, 1779).

424.6 Wesley, John (1703-91): Hymns for those that seek and those that have redemption in the blood of Jesus Christ, ninth edition (London: Printed by R. Hawes, 1776).

424.7 Wesley, Charles (1707-88): Gloria Patri, \&c. or, Hymns to the Trinity, sixth edition (London: Printed by Robert Hawes, 1775).

424.8 Wesley, John (1703-91): Graces. Before meat ([London: Printed by R. Hawes, c.1776]).

424.9 Wesley, John (1703-91): Hymns of intercession for all mankind (London: Printed by J. Paramore, 1790).

424.10 Wesley, John (1703-91): Funeral hymns, seventh edition (London: Printed by J. Paramore, 1784).

425 Wesley, John (1703-91): An extract from Milton's Paradise lost. With notes ([London: Printed by Henry Fenwick, 1763]).

'Mary Wesley 1763'

Note: Mary Goldhawke Vazeille (1710-81) married John Wesley in February 1751.

426 Clarendon, Edward Hyde, Earl of (1609-74): The life of Edward Earl of Clarendon, Vol. 2 (Oxford: At the Clarendon Printing-House, 1760).

427-29 Guthrie, William (1708-70): A general history of Scotland, from the earliest accounts to the present time, 10 vols (London: Printed for the author by A. Hamilton, 1767-68) (Vols 2-4 only).

430 Spenser, Edmund (1552?-99): The Faerie Queene (London: Printed for William Ponsonbie, 1596).

'C. Wesley, ex Æde Xti, 1734'; 'Sally Wesley 1776' 


\section{APPENDIX}

\section{A. Other Known Extant Volumes of Charles Wesley's Personal Library}

Butler, Samuel (1612-80): Hudibras. In three parts (London: Printed for D. Browne, et al., 1720)

(MARC, MA 5431).

'John Craven, ex aede Christi'; 'E lib. C. Wesley, aed. xti alum, ex dono amici Craven, Aug. 18. 1732'; 'Charles Wesley junr 1776' (crossed out); '[Miss] Sally Wesley 1776'

Note: $\quad$ The original donor is almost certainly John Craven (b. 1708), who entered Christ Church, Oxford, the same year as Charles Wesley.

Daubuz, Charles (1673-1717): A perpetual commentary on the Revelation of St. John; with a preliminary discourse concerning the principles upon which the said Revelation is to be understood. New modell'd, abridg'd, and render'd plain to the meanest capacity, by Peter Lancaster, second edition (London: Printed for the author and sold by W. Innys, 1730) (Archives of Kingswood School Library, Bath).

'C. Wesley' (on title page); 'E.A.P.J. Nov. 14, 1733' (on flyleaf)

Leusden, Johannes (1624-99): [Sefer Tehilim.] [Hebrew] Liber Psalmorum (London: S. Palmer, 1726) (Bridwell Library, Southern Methodist University, Texas).

'C. Wesley Mar. 1759'; 'Charles Wesley junr 1776'

Molinos, Miguel de (1628-96): The spiritual guide, which dis-intangles the soul; and brings it by the inward way, to the getting of perfect contemplation, and the rich treasure of internal peace ([London: s.n.], 1699) (Wesley Historical Society Library, Oxford Brookes University).

'C. Wesley 1755 '

Vives, Juan Luis (1492-1540), Erasmus Desiderius (d. 1536), et al.: De conscribendis epistolis, Des. Erasmi Roterodami opus. Ioannis Ludovici Vivis Valentini libellus verè aureus. Conradi Celtis methodus: Christophori Hegendorphini epitome. Omnia nunc demum in studiosorum gratiam \& utilitatem uno libello comprehensa, \& longè quàm antea emendatius excusa (Basel:

Nicolaum Brylingerum, 1561) (City Road Chapel, London).

'C. Wesley 17[ ]' [very faint]; 'Charles Wesley junr 1776'

Wesley, John (1703-91): A collection of Psalms and hymns (London: Printed by W. Strahan, 1741)

(MARC, DDCW/9/16).

'C[Wesley] [part of text cut off] 1741' 


\section{B. Other Known Volumes with Charles Wesley’s Inscription}

Huntingdon, Selina Hastings, Countess of (1707-91): The collection of hymns, sung in the Countess of Huntingdon's chapel (Bath: Printed by S. Hazard for T. Mills, 1770) (City Road Chapel, London).

'Charles Wesley to Charles Wesley Junior'

Wesley, Charles (1707-88): Hymns on the Trinity (Bristol: Printed by William Pine, 1767) (MARC, Charles Wesley Box 5).

'To Sally Barr, the gift of the author. May 4, 1767' (in Charles Wesley's hand)

Young, Edward (1683-1765): The complaint: or, Night-thoughts on life, death, and immortality (London: [s.n.], 1743) (MARC, MA 1977/582, Charles Wesley Notebooks, Box 3).

'Sally Hardwick's. The Gift of her Father' (in Charles Wesley's hand)

Note: Thomas Hardwick was a lay Methodist preacher from 1747 to 1748, who travelled at times with Charles Wesley. Charles performed the wedding of Hardwick to Sally Witham on 31 December 1748. It is unclear when and why he inscribed this volume. 